\title{
The Effect of Various Supplementary Irrigation Treatments on Plant and Soil Moisture Relationships in a Vineyard (Vitis Vinifera
} var. Chenin Blanc)

\author{
J. L. VAN ZYL ${ }^{1}$ and H. W. WEBER ${ }^{2}$ \\ 1. Oenological and Viticultural Research Institute, Private Bag X5026, Stellenbosch 7600 \\ 2. Department of Soil and Agricultural Water Science, Faculty of Agriculture, University of Stellenbosch, Stellenbosch, 7600
}

The authors wish to express their gratitude to Mr. C. V. van der Westhuizen for his willingness to put a vineyard at their disposal and for his unfailing co-operation and assistance.

\begin{abstract}
In a field plot trial with grape vines planted on a high potential soil, the soil moisture status on different irrigation treatment plots was compared with that of a dryland control. Soil moisture budgeting was based on physical soil properties and root distribution patterns before treatments commenced. A maximum concentration of roots occurred at the 300-450 mm depth zone, while approximately 90 per cent of the total number of roots was found above $900 \mathrm{~mm}$. Tensiometric readings of soil moisture potential, supplemented by electrometric resistance readings from gypsum blocks, indicated complete depletion between véraison and harvesting of the total available moisture on dryland plots.

Despite this severe moisture stress as illustrated by chrono-isopletes, a reasonably good grape yield was still produced by the dryland vines, indicating either exceptional drought resistance or the uptake of water from extraneous sources. Supplementary irrigations greatly improved soil moisture conditions during the important growth stages of (a) flowering and fruit set, (b) green berry stage and (c) véraison.

Moisture depletion patterns changed markedly as the season progressed from November to January, and as naturally stored rain water became depleted. In contrast to the absorption pattern in November, the fastest rate of water loss occurred in the deepest root zones during January, because of unsaturated moisture flow into the dry partly decomposed parent material. The apparently unproductive subsoil might act as a large natural reservoir for superfluous winter rain, which in summer becomes available to the vines through unsaturated upward flow into the root zone.

Determination of leaf water potential showed unexpectedly high values at night (minima of $-283 \mathrm{kPa}$ ) in plants growing in soil of which the major part was dried below wilting point. Vines were thus able to regain turgidity at night.

Crop factors for use with the American Class A-pan for scheduling irrigations were calculated. Crop factors were low (November to February $=0,20-0,30$ ), and again emphasised the ability of vines to use water frugally. Crop factors were strongly dependent upon soil moisture conditions. Empirical coefficients for use in the Blaney-Criddle formula are also presented.
\end{abstract}

Viticulture in dryland conditions is a long-established form of land use in the coastal regions of the Western Cape. Depending on the soil type, stored winter rain water provides largely for the water requirements of the vines during the almost rainless summer months. The inadequacy of this provision is indicated by visual drought symptoms in vineyards towards harvesting times and is due to severe soil moisture deficits. Many farmers have, therefore, started to irrigate but because of a limited supply of irrigation water only two or, maximally, three irrigations can be applied annually. However, a lack of knowledge existed with regard to the seasonal pattern of soil moisture depletion, the best time of the season to irrigate, and the response of the vine in this region traditionally known for the high quality of its wine.

Results from scientific vineyard irrigation experiments differ widely. Most researchers found an increased production with the maintenance of a high moisture level, i.e. an increased frequency of water application (Branas, 1967; Nijar \& Randhawa, 1968; Goldberg \& Shmueli, 1971; Smart, Turkington \& Evans, 1974). It is however, impossible to define a generally valid soil moisture level at which to start a new irrigation cycle, since several scientists (Zineberg \& Befani, 1962; Ashizawa, 1964; Voskanjan, 1966; Van Niekerk, 1968) suggested widely different regimes. This conclusion is apparently supported by the work of others, such as Nieuwoudt (1965), who found no differences at all in the responses of vines to different moisture regimes. Tatarenko (1971) and Lombardo (1972) even found a decrease in production with irrigation. These seemingly contradictory results may be attributed to differences in soils, and especially in climate, between experimental localities.

Apart from climatic and soil moisture conditions, the response of grape vines to irrigation is mainly determined by their growth stage (Alexander, 1964; Kasimatis, 1967; Hardie \& Considine, 1976). In general, growth and productivity are affected by the plant water status (Begg \& Turner, 1976), which serves as an excellent indicator of the availability of soil moisture to the plant. However, in practice direct measurement of plant water potential is of little use for the scheduling of irrigation. The American Weather Bureau Standard Class A-pan still offers the best practical method for the farmer to programme irrigations, provided reliable crop factors are known.

In order to find a locally applicable answer to the questions of how much, and when to irrigate when water

S. Afr. J. Enol. Vitic., Vol. 2. No. 2. 1981 
is in short supply, an experiment on the effect of limited irrigation was carried out in an established dryland vineyard.

Its aim was, firstly-

- to study the root systems of selected vines with respect to depth, ramification and density of distribution;

- to trace the seasonal pattern of moisture depletion in the soil by measuring both soil moisture and plant water potentials;

- to determine continually the evaporative demand of the atmosphere during the growing seasons by means of the Class A-pan, and to calculate appropriate crop factors;

- to check on the water needs of the vines during certain phenological stages;

and secondly-

- to integrate this information into a practical irrigation programme to be used by local farmers.

\section{MATERIALS AND METHODS}

Experimental Vineyard: The experiment was conducted in a 12-year old Chenin blanc vineyard grafted on 99R root-stock. The vines were planted $2,7 \times 1,2 \mathrm{~m}$, trellised on one wire $750 \mathrm{~mm}$ above soil level, and the soil was clean cultivated. Prior to the commencement of the trial (no irrigation water had been applied during the previous two seasons), the condition of the vines was assessed by measuring grape yield and pruning mass. Plant response to irrigation as regards productivity, shoot growth and wine quality was determined by standard techniques as described in a previous paper (Van Zyl \& Weber, 1977).

The soil of the experimental site is classified as a Clovelly soil form; Gutu serie (MacVicar \& Soil Survey Staff, DATS/RSA, 1977), which corresponds to the Inceptisols of the USDA-classification system (Soil Survey Staff, 1960). Clovelly soils are considered to have a high production potential for viticulture in the Stellenbosch area in spite of two unfavourable soil properties, viz., low $\mathrm{pH}$ and high bulk densities in the subsoil. The Clovelly soil encountered in this study had a $\mathrm{pH}=5,0(1 \mathrm{~N} \mathrm{KCl})$ throughout the profile, except below $600 \mathrm{~mm}$, where a $\mathrm{pH}<4,35(1 \mathrm{~N} \mathrm{KCl})$ and a bulk density of $1,60-1,70$ were found.

Physical Soil Properties: Before commencing the treatments a comprehensive pedological survey was carried out on representative sites in the experimental vineyard. During the same operation root distribution was investigated by applying the technique of mapping roots on a profile wall which ran parallel to the vine rows and 500 $\mathrm{mm}$ from the vine. Subsequently, the soil was sampled in $150 \mathrm{~mm}$ increments to a depth of $1200 \mathrm{~mm}$ for chemical and mechanical analyses. Undisturbed soil cores (volume $=69 \mathrm{~cm}^{3}$ ) were taken in triplicate at the same depths. The latter samples were used for determining various soil physical parameters, such as bulk density, saturated hydraulic conductivity, soil water retention curves, and "soil water constants", employing standard pressure plate equipment and soil porosity.

Field capacity of the soil was determined in situ by using a tensiometric and gravimetric technique (Hensley,
1970 ), saturation of $5,0 \times 2,7 \mathrm{~m}$ plots, and covering the soil with straw and plastic sheeting to prevent evaporation. Immediately after saturation, measurements of the soil moisture potential and soil moisture content at different depths were started, using mercury manometer type tensiometers and soil sampling, respectively. At first, sampling and soil moisture potential readings took place at short intervals (two hours) but the intervals were progressively increased, and the whole operation continued for ten days, by which time the soil moisture content had already been relatively constant. Field capacity was assumed when the moisture content became constant.

Measurement of Soil Moisture Status: The moisture status of the soil was followed mainly with the aid of Bourdontype tensiometers installed at five depths viz., $150 \mathrm{~mm}$, $370 \mathrm{~mm}, 530 \mathrm{~mm}, 670 \mathrm{~mm}$ and $830 \mathrm{~mm}$ on five test plots. Laboratory-determined soil moisture retention curves were applied to convert soil moisture potential into moisture content and to do soil moisture budgeting. During those periods of the first season when the soil moisture potential exceeded the measuring range of tensiometers, moisture contents were determined gravimetrically. In the second season, however, the gravimetric method was discarded in favour of gypsum blocks.

Gypsum blocks were calibrated in the laboratory (Bouyoucos \& Mick, 1940) in soil obtained from the respective soil horizons in the field. Each gypsum block was installed in a $150 \mathrm{~cm}^{3}$ beaker by compacting the soil around the blocks to field bulk density. Calibration curves were then established by saturating the soil, taking regular electrometric readings, and weighing the beaker with its contents during two drying cycles. Corrections were made for the moisture content of the gypsum blocks themselves.

The latter measuring devices were installed in undisturbed soil profile walls at the same depths as the tensiometers, but $1,2 \mathrm{~m}$ distant. All soil moisture measurements were made under the vines in the row, three times weekly (except in the case of the gravimetric moisture determination), and continued for the period from bud burst to harvesting during the 1973/74 and 1974/75 growing seasons of the vineyard.

Irrigation Treatments: Irrigation treatments consisted of the application or omission of an irrigation in each of the following three growth stages:

(i) Directly after flowering (approximately middle November)

(ii) During green berry state (approximately middle December)

(iii) At véraison (first half of January).

The 8 treatment combinations thus obtained (Table 1) were replicated 6 times, and the experimental plots allocated according to a randomised block design.

Plots were separated from one another by 4 buffer rows and by 3 buffer vines within each row.

Irrigations were applied by means of microjets (Series B $280^{\circ}$ ) with a delivery rate of $32 \ell / \mathrm{h}$ at a pressure of 100 $\mathrm{kPa}$, which wetted practically the entire soil surface. The application rate was $6,9 \mathrm{~mm} / \mathrm{h}$. The quantity of water 
given per irrigation was calculated from the moisture content of the soil and its water holding capacity to a depth of $900 \mathrm{~mm}$ after studying the root distribution of the vines.

TABLE 1

Eight irrigation treatments tested in a field trial on Chenin blanc near Stellenbosch

\begin{tabular}{cccc}
\hline \multicolumn{2}{c}{$\begin{array}{c}\text { Growth stages in which irrigations } \\
\text { were applied }\end{array}$} & \multirow{2}{*}{$\begin{array}{c}\text { Treatment } \\
\text { Code }\end{array}$} \\
\cline { 1 - 3 } Fruit set & Green Berry & Véraison & \\
\hline B & B & B & BBB \\
B & O & B & BOB \\
B & B & O & BBO \\
B & O & O & BOO \\
O & O & O & OOO \\
O & O & B & OOB \\
O & B & O & OBO \\
O & B & B & OBB \\
\hline
\end{tabular}

B - Irrigated

$\mathrm{O}$ - Non-irrigated

Meteorological Measurements: Together with soil moisture measurements, a limited number of meteorological elements viz., evaporation from the Standard American Weather Bureau Class A-pan, rainfall, relative humidity and air temperature were measured on the experimental site. Additionally, data from standard weather stations 8 kilometers from the experimental vineyard were also available. Class A-pan evaporation was used to calculate crop factors for the vineyard employing the formula

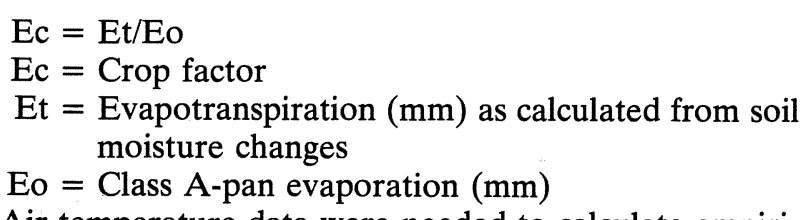

Air temperature data were needed to calculate empirical crop coefficients according to the formula of Blaney
\& Criddle (1950) for monthly calculations of evapotranspiration:

$$
\begin{aligned}
\mathrm{Et}= & 25,4 \mathrm{kp} \frac{(1,8 \mathrm{t}+32)}{100} \\
\mathrm{Et}= & \text { Evapotranspiration }(\mathrm{mm}) \\
\mathrm{k}= & \text { Monthly empirical crop coefficient dependent } \\
& \text { on the kind of crop and climatic region } \\
\mathrm{p}= & \text { Monthly percentage of the annual total of hours } \\
& \text { sunshine (supplied in tables for a specific lati- } \\
& \text { tude) } \\
\mathrm{t}= & \text { Monthly mean temperature }\left({ }^{\circ} \mathrm{C}\right)
\end{aligned}
$$

However, instead of using mean air temperature, maximum air temperature was employed in this study as suggested by Du Pisani (1972).

Leaf Water Potential: Leaf water potential was measured with a pressure chamber apparatus (Scholander, Hammel, Bradstreet \& Hemmingson, 1965) on vines of the two most extreme treatments viz., a dryland (control) plot (OOO) and a plot which received three irrigations per season (BBB). This determination was carried out before dawn when the leaves should have reached maximum turgidity (numerically the lowest leaf water potential). Eight to ten mature leaves per plot were picked and put in the pressure chamber immediately. Care was taken to use only mature leaves. The fourth or fifth leaf from the base of the shoot was taken in order to eliminate variation as far as possible.

\section{RESULTS AND DISCUSSION}

The root distribution pattern was affected by unfavourable physical conditions in the subsoil, as is indicated in Fig. 1.

Fig. 1

Schematic presentation of percentage roots (averages of 6 plots) found at different depths in the experimental vineyard.

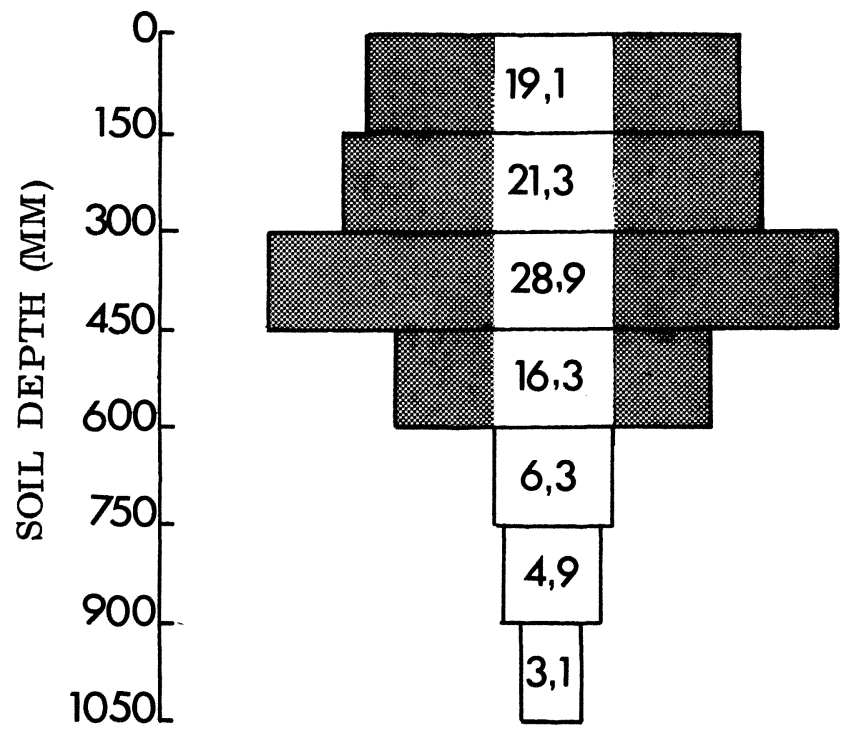

S. Afr. J. Enol. Vitic., Vol. 2. No. 2. 1981 
The diagram in Fig. 1 displays an average root distribution for six plots. Eighty-seven per cent of the total number of roots developed in the soil layers above 600 $\mathrm{mm}$. Contrary to the root distribution patterns of many plants, the highest concentration of roots $(28,9 \%)$ in this study was found in the $300-450 \mathrm{~mm}$ soil layer. The first $(0-150 \mathrm{~mm})$ and second $(150-300 \mathrm{~mm})$ layers contained $19,1 \%$ and $21,3 \%$ of the total number of roots, respectively. Dryland conditions (high temperatures and low moisture content in summer) are not conducive to root growth in the upper layers, and vine roots will favour deeper soil horizons. According to Russel (1977), a restriction of growth in part of the root system may lead to increased growth of more favourably placed root members. Clean cultivation resulted in practically no roots in the upper $100 \mathrm{~mm}$ of the soil, as can be seen in Fig. 2, which also shows that the largest percentage of coarse roots occurred in the $300-450 \mathrm{~mm}$ layer. It is, however, not yet clear how water absorption is affected by root diameter. Considering the root distribution pattern, soil moisture measurements and budgeting were done only for the upper $900 \mathrm{~mm}$ of the soil.

\section{FIG. 2}

Distribution and relative thickness of Chenin blanc/99R roots in the experimental vineyard (Plot No. vi).

DISTANCE FROM THE VINE (MM)

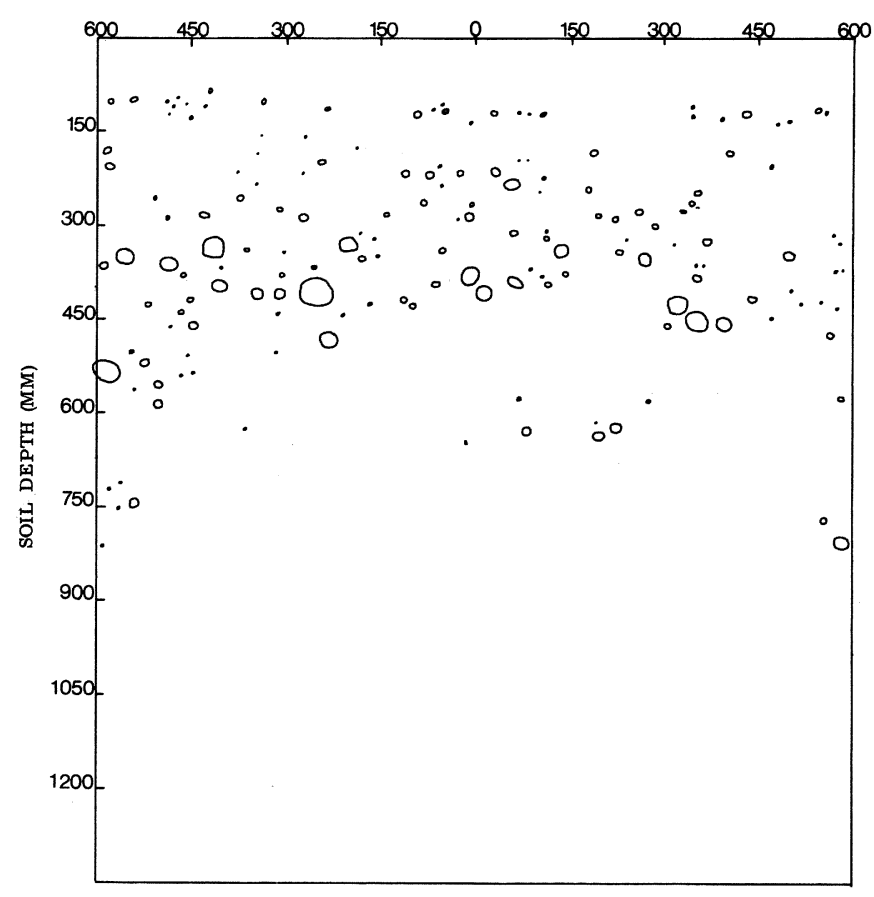

Total Available Moisture (TAM): The redistribution of soil moisture, following saturation during the determination of Field Capacity is presented in Fig. 3 for one experimental plot. This process reached the so-called "equilibrium" after about 48 hours in the $0-300 \mathrm{~mm}$ soil layers, but only after approximately 100 hours in the deeper (and more clayey) horizons. Field Capacity values were assessed on the basis of gravimetric moisture determinations which are somewhat "insensitive" to small changes in water content due to inherent weaknesses in soil sampling techniques. Examination of Fig. 3 further shows that the soil moisture potential continued to decrease even after field capacity was assumed, thus indicating continuation of water loss. According to Hillel (1971), the redistribution of water in soil is in fact continuous and exhibits no abrupt "breaks" or static levels; it can in certain soils continue for months in the absence of evapotranspiration. However, for irrigation scheduling purposes field capacity was accepted as a characteristic of, and a constant for, the soil. It should further be borne in mind that plants are capable of absorbing free water (Hillel, 1971; Black, 1976), and that in a growing vineyard drainage of superfluous water will soon be stopped by normal evapotranspiration losses. The water content of undisturbed soil cores at $-1500 \mathrm{kPa}$, determined in a pressure plate extractor, was accepted as the lower limit of plant available moisture i.e. Permanent Wilting Point.

Table 2 shows the TAM at field capacity for four experimental plots. The values varied between $83 \mathrm{~mm}$ and $89 \mathrm{~mm}$ for a rooting depth of $900 \mathrm{~mm}$. For the light-textured ( $<10 \%$ clay) A- and B21-horizons the moisture content at field capacity corresponds to a soil water potential of approximately $-6 \mathrm{kPa}$, but in the more clayey (15-23\% clay) subsoil field capacity was reached at $-10 \mathrm{kPa}$.

Functioning of Moisture Measuring Instruments: The Bourdon type tensiometers used in this study functioned satisfactorily. Changes of $1 \mathrm{kPa}$ in soil moisture potential could easily be registered. Fig. 4 presents calibration curves for the conversion of tensiometer readings to soil moisture content. A change of $1 \mathrm{kPa}$ in soil moisture potential corresponded to 0,45 volume per cent moisture $(0,45 \mathrm{~mm} / 10 \mathrm{~cm}$ depth $)$ at field capacity. In the drier range much smaller changes in water content in the soil could be detected due to the specific pattern of soil moisture retention curves.

In the light textured (clay content $<10 \%$ ) soil of the A- and B21-horizons, tensiometers were able to measure $60-70 \%$ of the available moisture. Tensiometer readings in the heavier textured (clay content $=15-23 \%$ ) B22horizons could only register $50-55 \%$ of the available moisture before air entered the apparatus.

A statistical analysis done on total available moisture contents derived from tensiometer-readings of 4 replicate plots scattered throughout the experimental vineyard, revealed no significant differences in moisture content (a 7 week period was used) between plots. Not only did the tensiometers function well, but moisture in the vineyard was also depleted very uniformly due to the homogeneity of the soil.

Electrometric resistance measurements with Bouyoucos gypsum blocks were converted to soil moisture content using calibration curves (Fig. 5).

These curves are similar in shape to those of Colman (1952). At high moisture contents (near field capacity) the gypsum block readings were in general unreliable. However, at lower moisture content the total available moisture measured by both gypsum blocks and tensiometers yielded comparable results (Fig. 6). Nevertheless it was found that tensiometers were more sensitive to small changes in moisture content than gypsum blocks. 


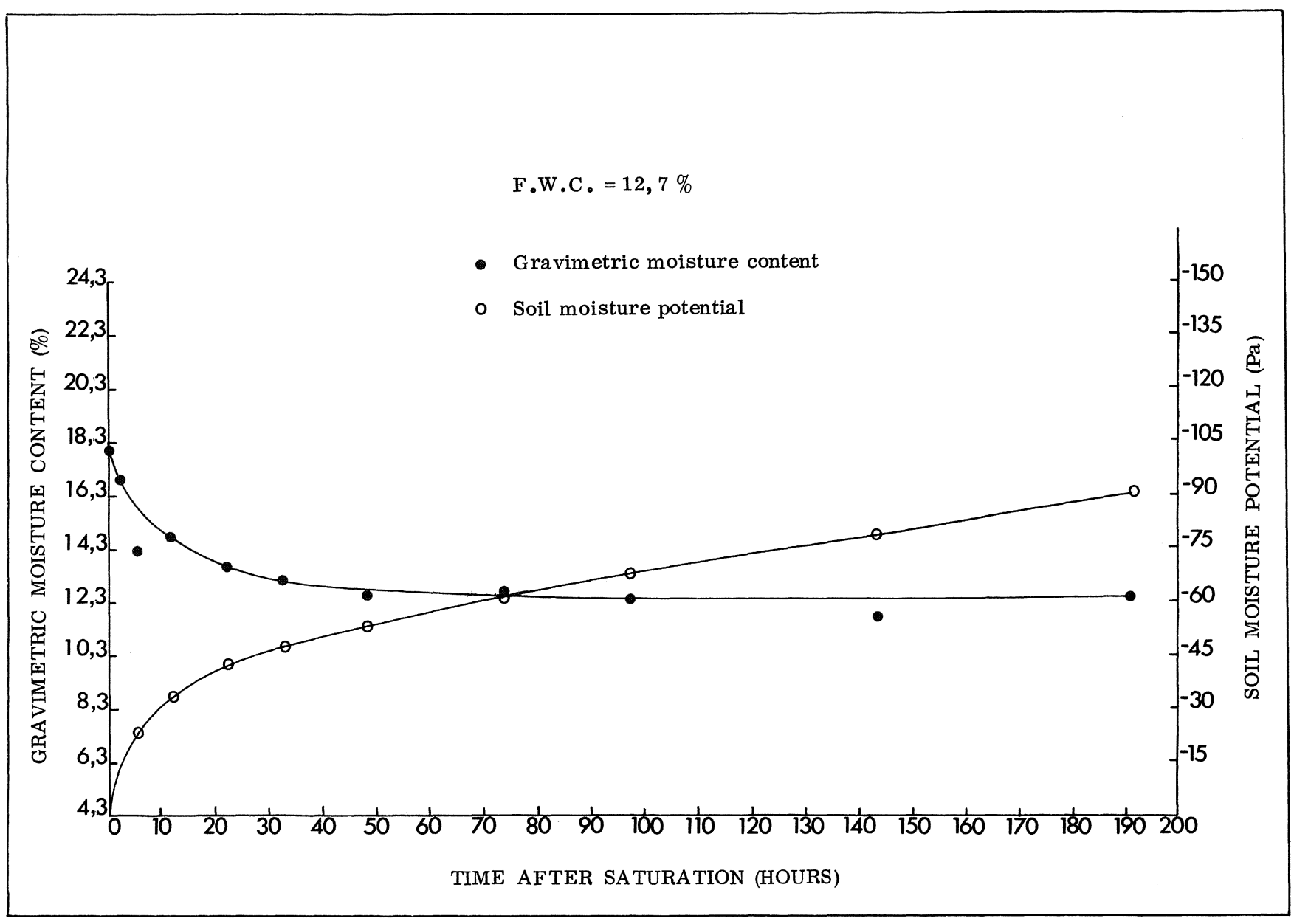

FIG. 3

Redistribution of soil moisture after saturation as determined by gravimetric and tensiometric methods.

TABLE 2

The moisture holding capacity of four plots in the experimental vineyard

\begin{tabular}{|c|c|c|c|c|c|c|}
\hline \multirow{2}{*}{$\begin{array}{l}\text { Soil } \\
\text { Depth } \\
(\mathrm{mm})\end{array}$} & \multicolumn{3}{|c|}{ Plot No. I } & \multicolumn{3}{|c|}{ Plot No. IV } \\
\hline & $\begin{array}{l}\text { Field } \\
\text { Capacity } \\
(\mathrm{mm})\end{array}$ & $\begin{array}{l}\text { Wilting } \\
\text { Point } \\
\text { (mm) }\end{array}$ & $\begin{array}{c}\text { Available } \\
\text { Moisture } \\
\text { (mm) }\end{array}$ & $\begin{array}{c}\text { Field } \\
\text { Capacity } \\
(\mathrm{mm})\end{array}$ & $\begin{array}{l}\text { Wilting } \\
\text { Point } \\
(\mathrm{mm})\end{array}$ & $\begin{array}{c}\text { Available } \\
\text { Moisture } \\
(\mathrm{mm})\end{array}$ \\
\hline $\begin{array}{r}0-100 \ldots \ldots \\
100-200 \ldots \ldots \\
200-300 \ldots \ldots \\
300-450 \ldots \ldots \\
450-600 \ldots \ldots \\
600-750 \ldots \ldots \\
750-900 \ldots \ldots \\
\end{array}$ & $\begin{array}{l}16,13 \\
16,86 \\
18,45 \\
26,51 \\
30,91 \\
29,44 \\
30,75 \\
\text { To }\end{array}$ & $\begin{array}{c}6,48 \\
6,53 \\
7,42 \\
11,67 \\
15,72 \\
16,63 \\
17,98 \\
\text { Moistu }\end{array}$ & $\begin{array}{r}9,65 \\
10,36 \\
11,03 \\
14,84 \\
15,19 \\
12,81 \\
12,77 \\
\text { nm }\end{array}$ & $\begin{array}{l}17,51 \\
17,77 \\
18,27 \\
29,67 \\
31,30 \\
30,75 \\
31,13 \\
\text { To }\end{array}$ & $\begin{array}{r}8,40 \\
8,40 \\
8,29 \\
15,26 \\
16,70 \\
17,37 \\
17,53 \\
\text { Moistu }\end{array}$ & $\begin{array}{r}9,12 \\
9,36 \\
9,98 \\
14,41 \\
14,60 \\
13,38 \\
13,60 \\
\text { nm }\end{array}$ \\
\hline $750-900 \ldots \ldots \ldots$ & \multicolumn{3}{|c|}{ Plot No. V } & \multicolumn{3}{|c|}{ Plot No. VI } \\
\hline $\begin{array}{r}0-100 \ldots \ldots \ldots \\
100-200 \ldots \ldots \ldots \\
200-300 \ldots \ldots \ldots \\
300-450 \ldots \ldots \ldots \\
450-600 \ldots \ldots \ldots \\
600-750 \ldots \ldots \ldots \\
750-900 \ldots \ldots \ldots\end{array}$ & $\begin{array}{l}17,65 \\
17,78 \\
17,80 \\
28,25 \\
30,34 \\
30,75 \\
30,75\end{array}$ & $\begin{array}{r}8,21 \\
8,26 \\
8,16 \\
15,00 \\
16,42 \\
17,27 \\
16,92\end{array}$ & $\begin{array}{r}9,44 \\
9,52 \\
9,64 \\
13,25 \\
13,92 \\
13,48 \\
13,83\end{array}$ & $\begin{array}{l}17,02 \\
18,92 \\
18,45 \\
27,86 \\
31,49 \\
32,06 \\
31,88\end{array}$ & $\begin{array}{r}7,79 \\
8,17 \\
8,25 \\
13,41 \\
16,53 \\
17,16 \\
17,16\end{array}$ & $\begin{array}{r}9,23 \\
10,75 \\
10,20 \\
14,45 \\
14,96 \\
14,90 \\
14,72\end{array}$ \\
\hline & \multicolumn{3}{|c|}{ Total Available Moisture $=83,08 \mathrm{~mm}$} & \multicolumn{3}{|c|}{ Total Available Moisture $=89,21 \mathrm{~mm}$} \\
\hline
\end{tabular}




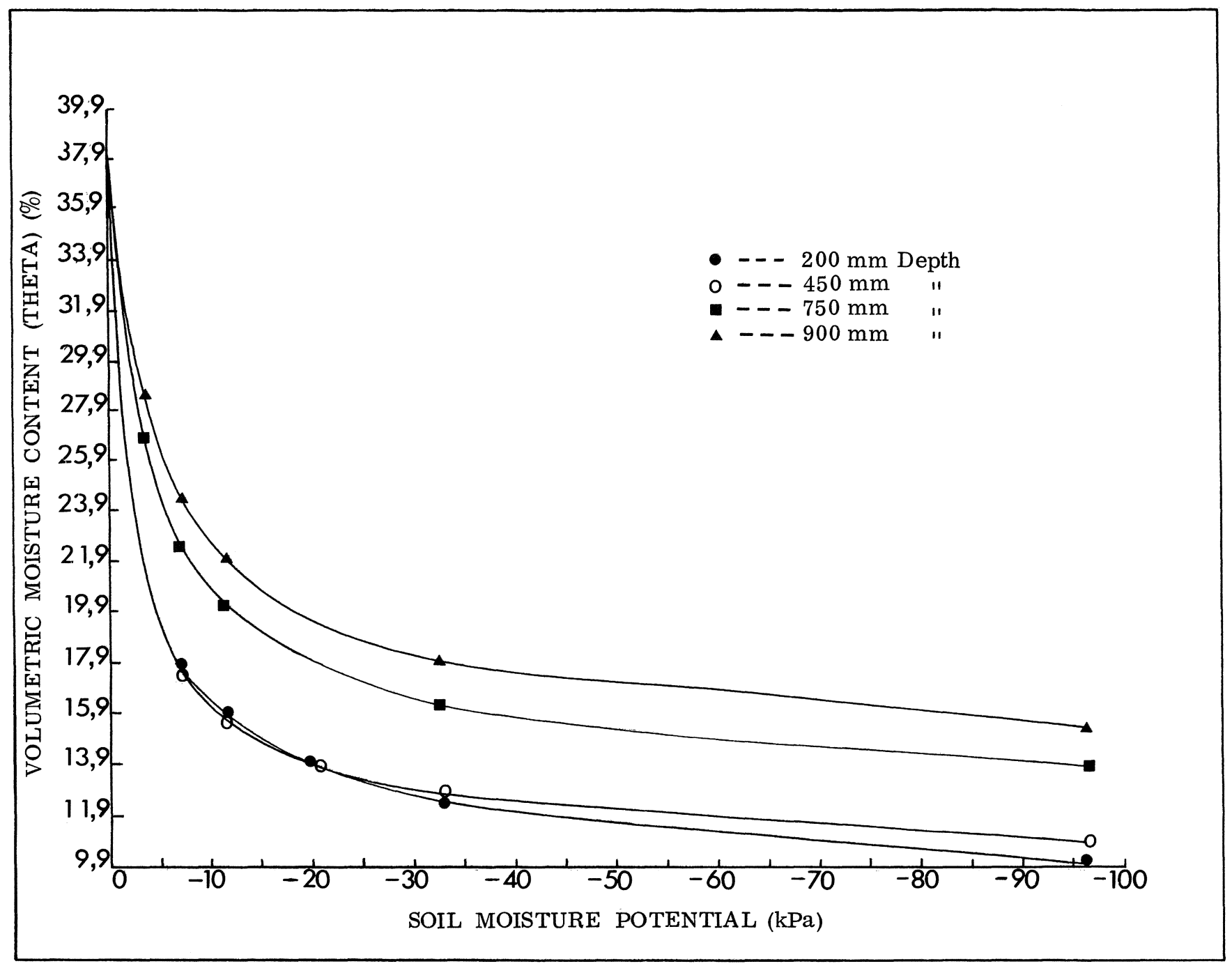

FIg. 4

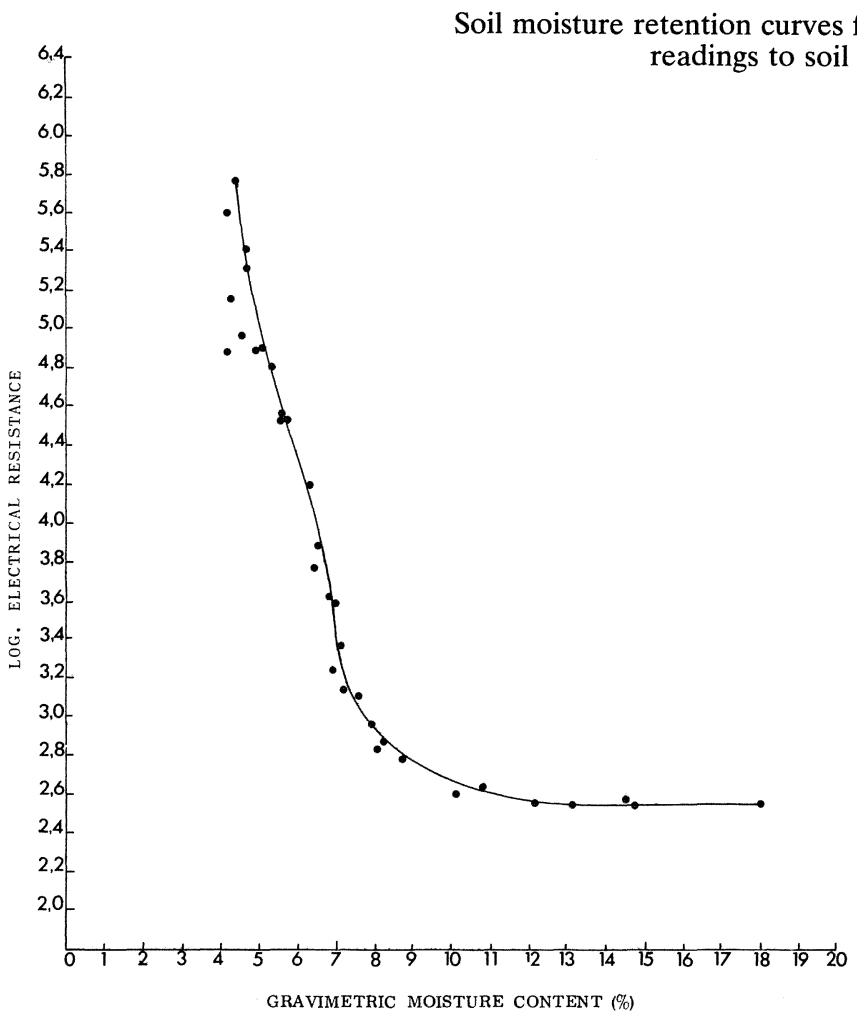

FIG. 5

Calibration curve for a Bouyoucos gypsum block.

S. Afr. J. Enol. Vitic., Vol. 2. No. 2. 1981 


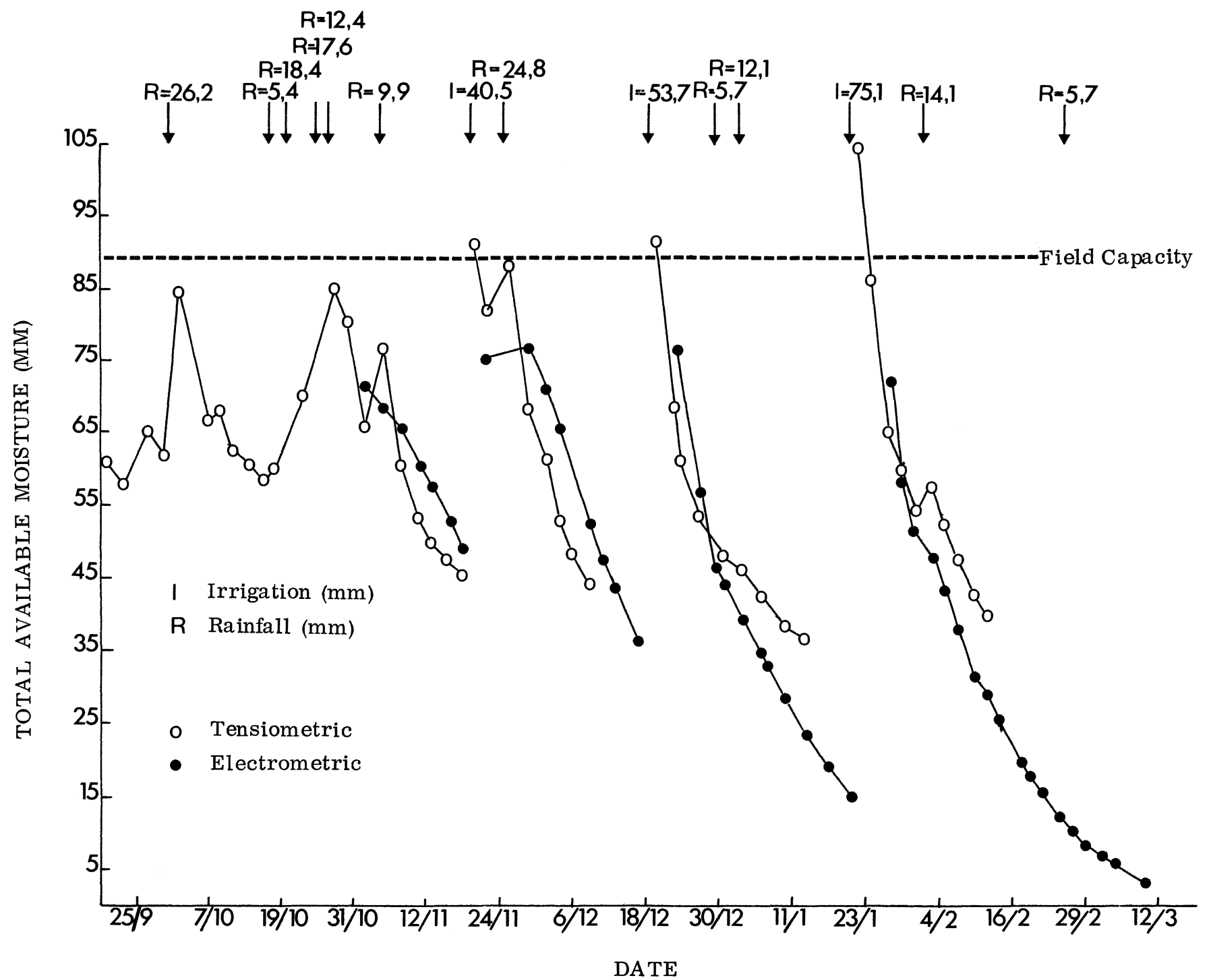

FIG. 6

Total Available Moisture calculated from both tensiometric and electrometric (gypsum blocks) readings during the 1974/75 season (BBB treatment).

Soil Moisture Levels and Growth Stages of the Vines: Average long term rainfall data for the Stellenbosch area are presented graphically in Fig. 7, while the changes in TAM content of four treatments are presented in Fig. 8. These 4 treatments, representing the most important growth stages with regard to irrigation are:

(i) Irrigations at flowering and véraison ( $\mathrm{BOB}$ )

(ii) Irrigations at the green berry stage and véraison (OBB)

(iii) Dryland control (OOO)

(iv) Irrigations at flowering, green berry stage and véraison $(\mathrm{BBB})$.

In the Stellenbosch area with its typical mediterranean climate, the effective rainfall decreased sharply after October (Fig. 7), leaving the vines to grow and produce solely on soil moisture reserves. Soil moisture measurements gave valuable information on the water supply to dryland vines. During the vegetative period from bud burst, third week of September, to flowering, second week of November, in both the 1973/74 and 1974/75 seasons, the soil moisture reservoir, filled during winter and replenished regularly during early spring, was capable of supplying an adequate quantity of water to the vines at beneficially high soil water potentials. Average rainfall data are closely in accord with those of the two seasons mentioned above. It can, therefore, be accepted that irrigations during this first stage of the growing season will seldom be necessary.

In both seasons all plant available moisture in dryland plots was depleted during the second half of January. However, severe shortages of water occurred earlier, since the moisture content of the upper soil horizons containing the largest number of roots reached wilting point much earlier (see discussion further on). A much more favourable soil moisture content was provided by irrigation (Fig. 8) in comparison with the control plots. Between irrigations the moisture content decreased to 


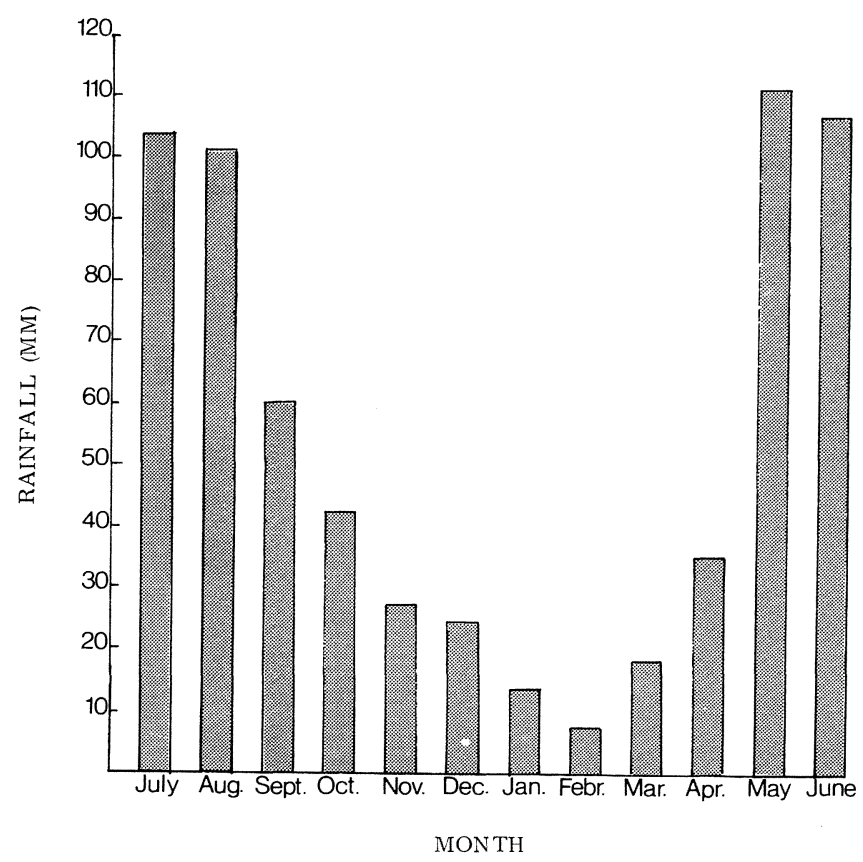

FIG. 7

Long term mean monthly rainfall $(\mathrm{mm})$ for the Stellenbosch area.

FIG. 8

Changes during the 1974/75 season in total available moisture content of a Clovelly soil planted to vines.

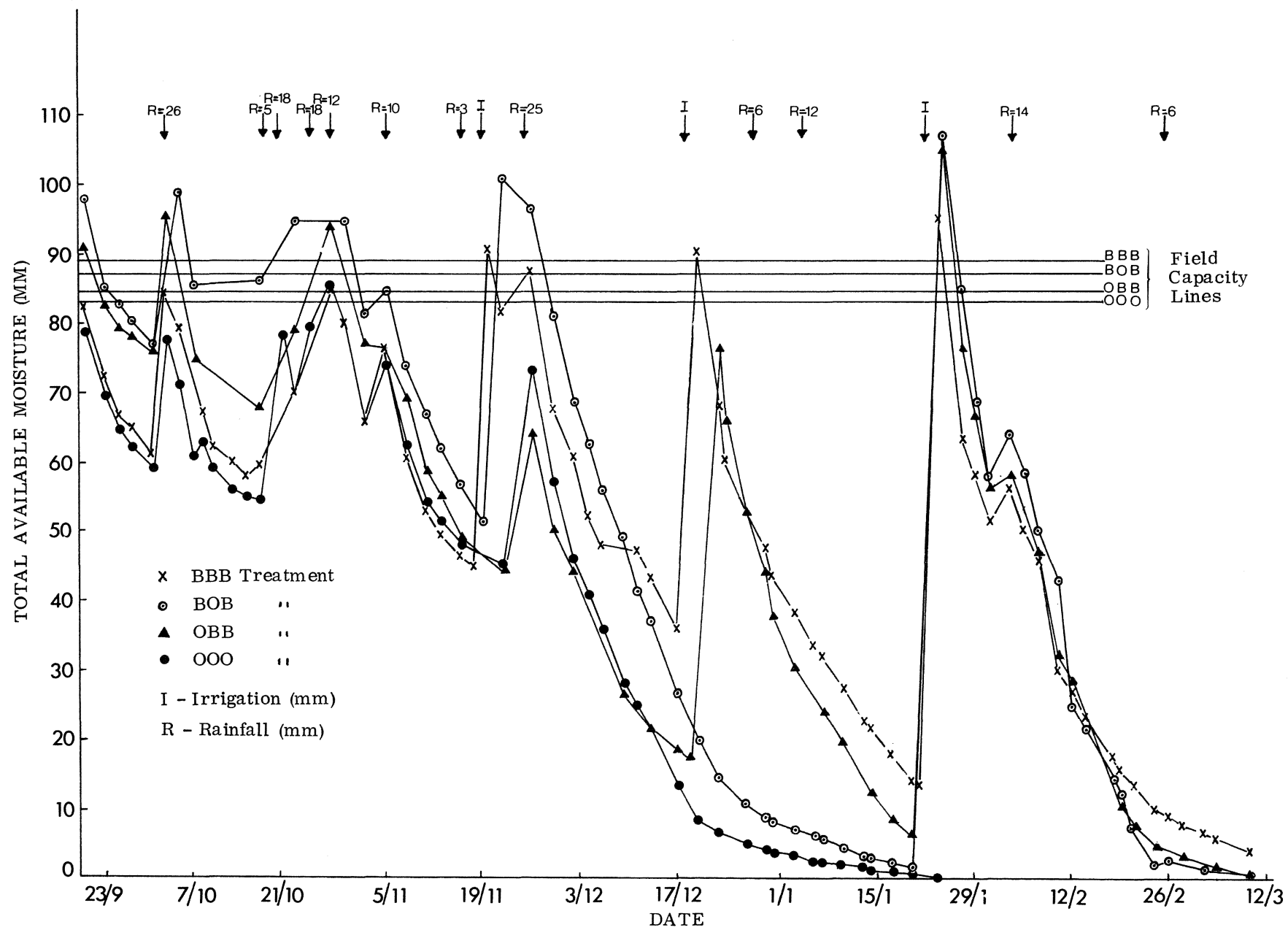

S. Afr. J. Enol. Vitic., Vol. 2. No. 2. 1981 
levels much lower than those which are generally used for irrigation scheduling, namely 50\% TAM.

The soil moisture content of the four treatments under discussion directly before irrigations and harvesting are presented as moisture levels i.e. percentage of the TAM still present in the soil, in Table 3.

Moisture levels at flowering, just before the first irrigation, varied between 50 and $60 \%$. Although an irrigation, when judging from the moisture level, could therefore still have been postponed, water was applied to coincide with the flowering and fruit set period of the vines. In the second season $25 \mathrm{~mm}$ of rain fell 7 days after this first irrigation. The moisture content of both unirrigated plots was increased significantly (Fig. 8). Tensiometer readings (not shown here) indicated that field capacity was attained in the $0-300 \mathrm{~mm}$ zones, while, even in the 300-450 mm zones, a moisture increase was discernible. Despite this, the beneficial effect of irrigation was still apparent. The irrigation at flowering led to a highly significant increase in grape yield (Van Zyl \& Weber, 1977), thus emphasising the sensitivity of the vine to moisture stress during fruit set and the first stage of rapid berry enlargement. Furthermore, this favourable response was obtained with a nett quantity of approximately $40 \mathrm{~mm}$ of water.

Prior to the irrigation in the green berry stage (middle December), the plots of the two treatments OBB and OOO which did not receive an earlier irrigation were respectively at moisture levels of $29 \%$ and $28 \%$ in 1973/ 74 , and $17 \%$ and $16 \%$ in $1974 / 75$. However, the previously irrigated treatments were at higher moisture levels, as can be seen in Table 3. Judging from soil moisture content alone, the vines should, therefore, have benefited greatly from an irrigation at that stage. The response of the vineyard to irrigation water was, however, disappointing (Van Zyl \& Weber, 1977). This was probably due to the fact that the vines were not in a critical stage, and later water applications could compensate for the possible negative effect of moisture stress at that stage.

Examination of Fig. 8 and Table 3 shows very low moisture contents in all treatments at véraison. Considering the important changes that take place in grapes during véraison, viz., a sharp increase in berry volume, increase in sugar concentration, decrease in tartaric and malic acid contents (Van Zyl \& Van Huyssteen, 1980), an irrigation during the first stages of ripening should have a beneficial effect, as was shown by Van Zyl \& Weber (1977). The nett quantity of irrigation water needed to attain field capacity throughout the root zone varied between $75 \mathrm{~mm}$ and $102 \mathrm{~mm}$. After the final irrigation the soil dried again rapidly to wilting point at harvesting five to six weeks later.

Moisture Extraction Patterns with Depth: In Fig. 9, 10 \& 11 moisture depletion in the different soil layers during the 1974/75 season is illustrated by means of chronoisopletes (Scheffer \& Schachtschabel, 1970) for three treatments. This graphic representation is very useful, since in addition to moisture extraction patterns, it also shows very clearly the effect of rainfall and irrigation on the soil moisture content.

Chrono-isopletes for the OOO-treatment (Fig. 9) indicate an even worse moisture situation than is illustrated by the TAM-curves (Fig. 8). From the end of December in 1974/75 the soii was at wilting point down to a depth of $600 \mathrm{~mm}$, while the small quantity of available water in the $600-900 \mathrm{~mm}$ zone was held at a very low potential. It can be accepted, therefore, that evapotranspiration at this stage was determined by soil resistance to moisture movement (Ferguson, 1965), in contrast to the situation of moisture being readily available throughout the soil profile, in which case evapotranspiration is principally determined by climatic conditions. According to Ferguson's (1965) hypothesis, evapotranspiration is mainly determined by leaf resistance to transpiration in cases where the soil surface has dried, and the moisture content in the rest of the soil profile is intermediate.

From the examination of tensiometer and rainfall data some consequences arise as to the effectivity of rainfall. Early in the season, when moisture levels were still high, a rainfall of $10 \mathrm{~mm}$ effectively replenished the moisture content of the $0-300 \mathrm{~mm}$ root zone. A rainfall of $12 \mathrm{~mm}$ at the beginning of January, however, did not even affect tensiometer readings at $150 \mathrm{~mm}$ depth on any one of the experimental plots. A downpour of $14 \mathrm{~mm}$ at the beginning of February was well registered at the $150 \mathrm{~mm}$ depth of the OOO-plot, but the contribution to the soil moisture content was negligibly small. However, in the case of the irrigated plots (Fig. $10 \& 11$ ), which at that stage were still at higher moisture levels, the same $14 \mathrm{~mm}$ rain contributed effectively to the soil moisture replenishment in the $0-300 \mathrm{~mm}$ root zone. The moisture content of the

TABLE 3

Moisture levels and appropriate irrigation water quantities at important growth stages of wine grapes in different treatment plots

\begin{tabular}{|c|c|c|c|c|c|c|c|c|c|}
\hline \multirow{2}{*}{$\begin{array}{c}\text { Irrigation } \\
\text { and } \\
\text { Harvesting } \\
\text { Dates }\end{array}$} & \multirow{2}{*}{$\begin{array}{l}\text { Growth } \\
\text { Stage }\end{array}$} & \multicolumn{2}{|c|}{ BOB } & \multicolumn{2}{|c|}{ OBB } & \multicolumn{2}{|c|}{ OOO } & \multicolumn{2}{|c|}{ BBB } \\
\hline & & $\begin{array}{l}\text { Moisture } \\
\text { Level (\%) }\end{array}$ & $\begin{array}{l}\text { Irrigation } \\
\quad(\mathrm{mm})\end{array}$ & $\begin{array}{l}\text { Moisture } \\
\text { Level (\%) }\end{array}$ & $\begin{array}{l}\text { Irrigation } \\
(\mathrm{mm})\end{array}$ & $\begin{array}{l}\text { Moisture } \\
\text { Level (\%) }\end{array}$ & $\begin{array}{l}\text { Irrigation } \\
(\mathrm{mm})\end{array}$ & $\begin{array}{l}\text { Moisture } \\
\text { Level (\%) }\end{array}$ & $\begin{array}{l}\text { Irrigation } \\
(\mathrm{mm})\end{array}$ \\
\hline $\begin{array}{l}13 / 11 / 73 \ldots \ldots \\
12 / 12 / 73 \ldots \ldots \\
23 / 1 / 74 \ldots \ldots \\
11 / 2 / 74 \ldots \ldots\end{array}$ & $\begin{array}{l}\text { Flowering } \\
\text { Green Berry } \\
\text { Véraison } \\
\text { Pre-Harvest }\end{array}$ & $\begin{aligned} & 56,9 \\
& 52,4 \\
< & \text { PWP* } \\
< & \text { PWP }\end{aligned}$ & $\begin{array}{c}37,4 \\
\overline{102,2} \\
-\end{array}$ & $\begin{aligned} & 52,6 \\
& 29,5 \\
&< \\
&<\text { PWP } \\
&<\text { PWP }\end{aligned}$ & $\begin{array}{c}- \\
59,6 \\
88,3 \\
-\end{array}$ & $\begin{aligned} & 50,4 \\
& 28,5 \\
&< \\
&<\text { PWP } \\
&<\text { PWP }\end{aligned}$ & $\begin{array}{l}- \\
-\end{array}$ & $\begin{array}{c}51,0 \\
43,7 \\
9,8 \\
\approx \text { PWP }\end{array}$ & $\begin{array}{c}43,4 \\
50,3 \\
80,5 \\
-\end{array}$ \\
\hline $\begin{array}{l}18 / 11 / 74 \ldots \ldots \\
18 / 12 / 74 \ldots \ldots \\
21 / 1 / 75 \ldots \ldots \\
6 / 3 / 75 \ldots \ldots\end{array}$ & $\begin{array}{l}\text { Flowering } \\
\text { Green Berry } \\
\text { Véraison } \\
\text { Pre-Harvest }\end{array}$ & $\begin{aligned} & 59,1 \\
& 30,1 \\
< & \text { PWP } \\
< & \text { PWP }\end{aligned}$ & $\begin{array}{c}35,4 \\
\overline{92,0} \\
-\end{array}$ & $\begin{array}{c}55,0 \\
16,9 \\
3,0 \\
<\text { PWP }\end{array}$ & $\begin{array}{l}\overline{70,2} \\
82,0 \\
-\end{array}$ & $\begin{aligned} & 56,3 \\
& 15,8 \\
< & \text { PWP } \\
< & \text { PWP }\end{aligned}$ & $\frac{-}{-}$ & $\begin{aligned} & 55,0 \\
& 39,8 \\
& 15,9 \\
& \approx \text { PWP }\end{aligned}$ & $\begin{array}{l}40,5 \\
53,7 \\
75,1 \\
-\end{array}$ \\
\hline
\end{tabular}

${ }^{*}$ PWP $=$ Permanent Wilting Point 


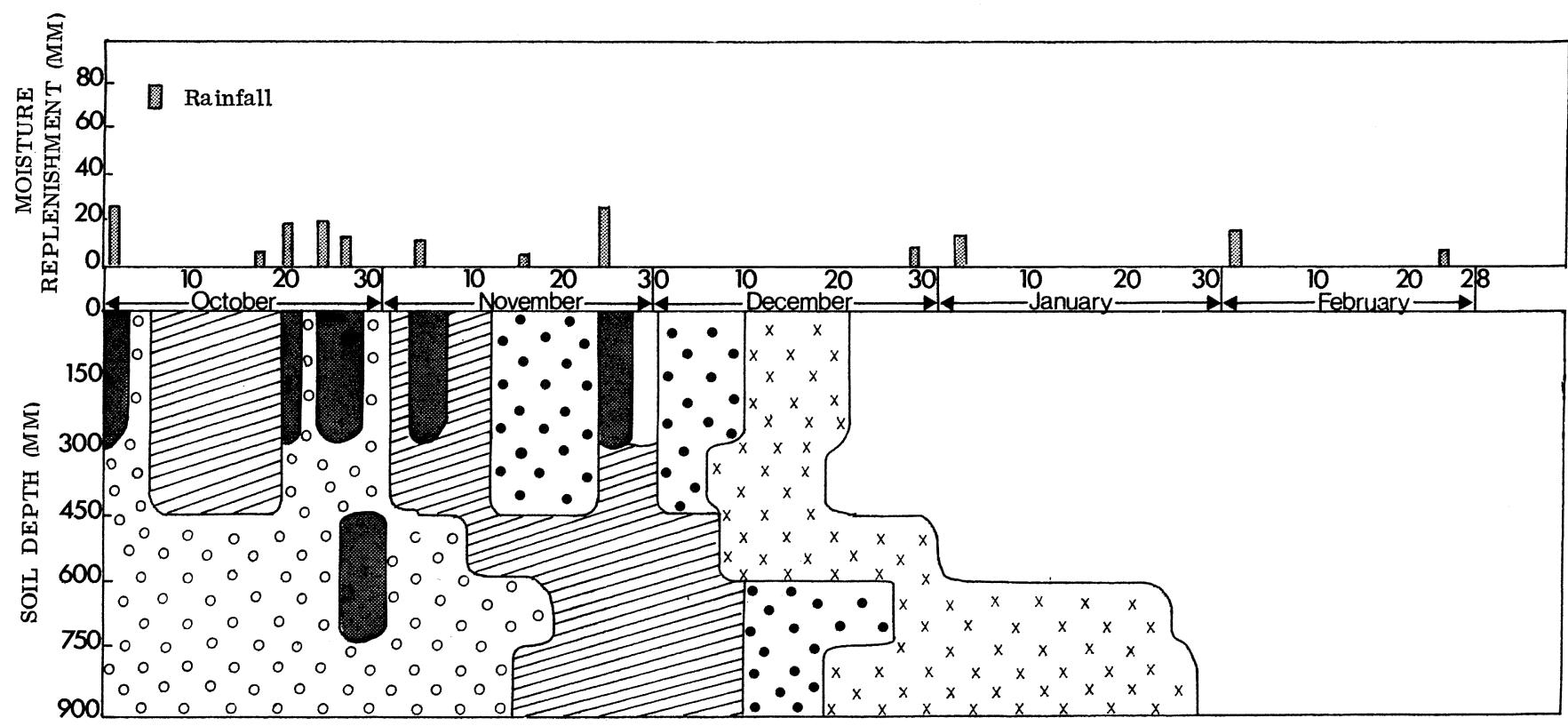

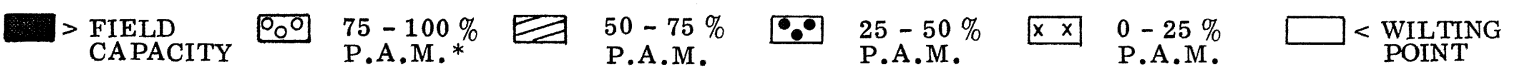

*P.A.M. Plant Available Moisture

FIG. 9

Soil water content with depth in the non-irrigated (OOO) treatment during the $1974 / 75$ season.

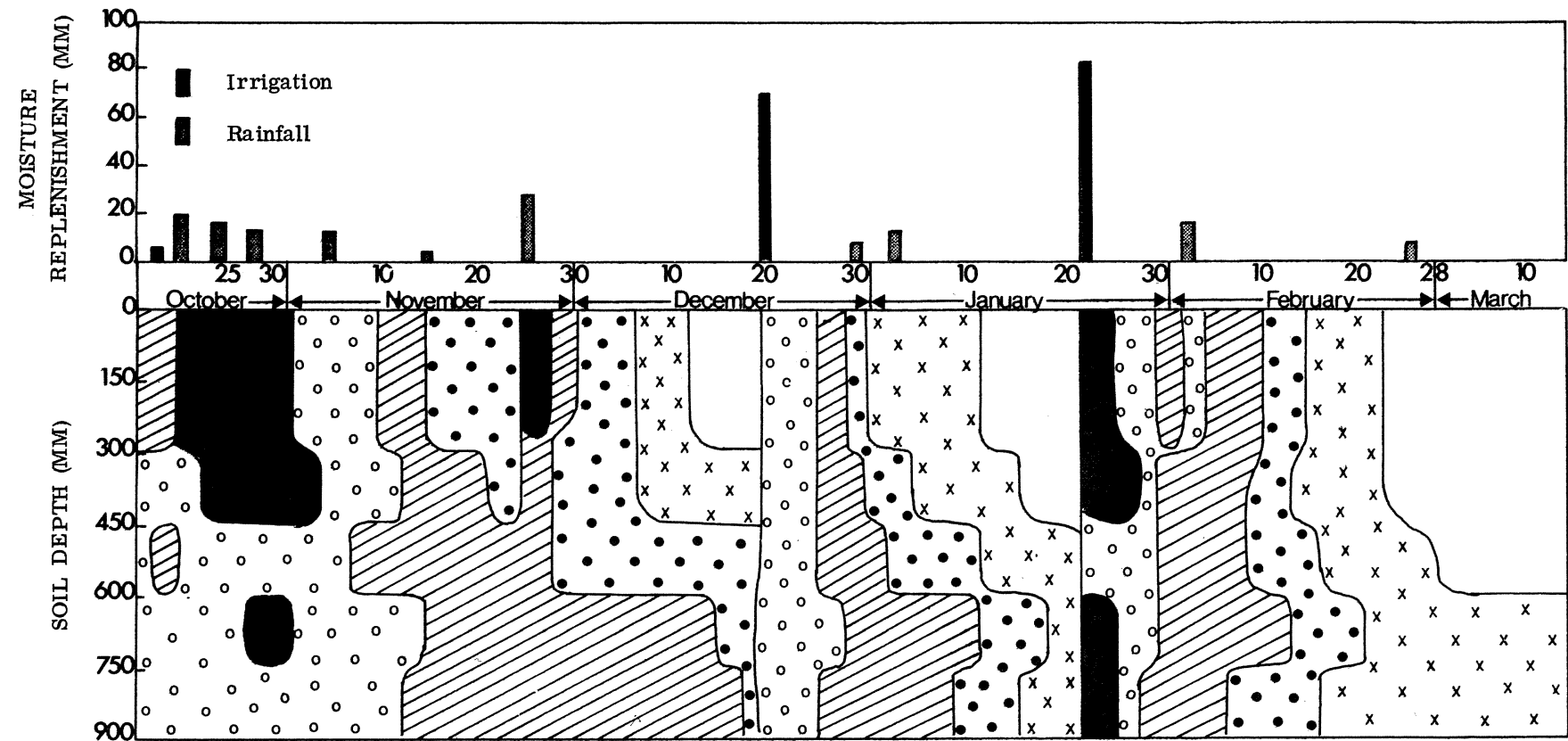
> FIELD
O०
$75-100 \%$
$50-75 \%$
E.0 $25-50 \%$
P.A.M.
$0-25 \%$
$<$ WILTING
CAPACITY
P.A.M.*
P.A.M.
P.A.M.
POINT

P.A.M. Plant Available Moisture

FIG. 10

Soil water content with depth in the OBB treatment during the $1974 / 75$ season. 


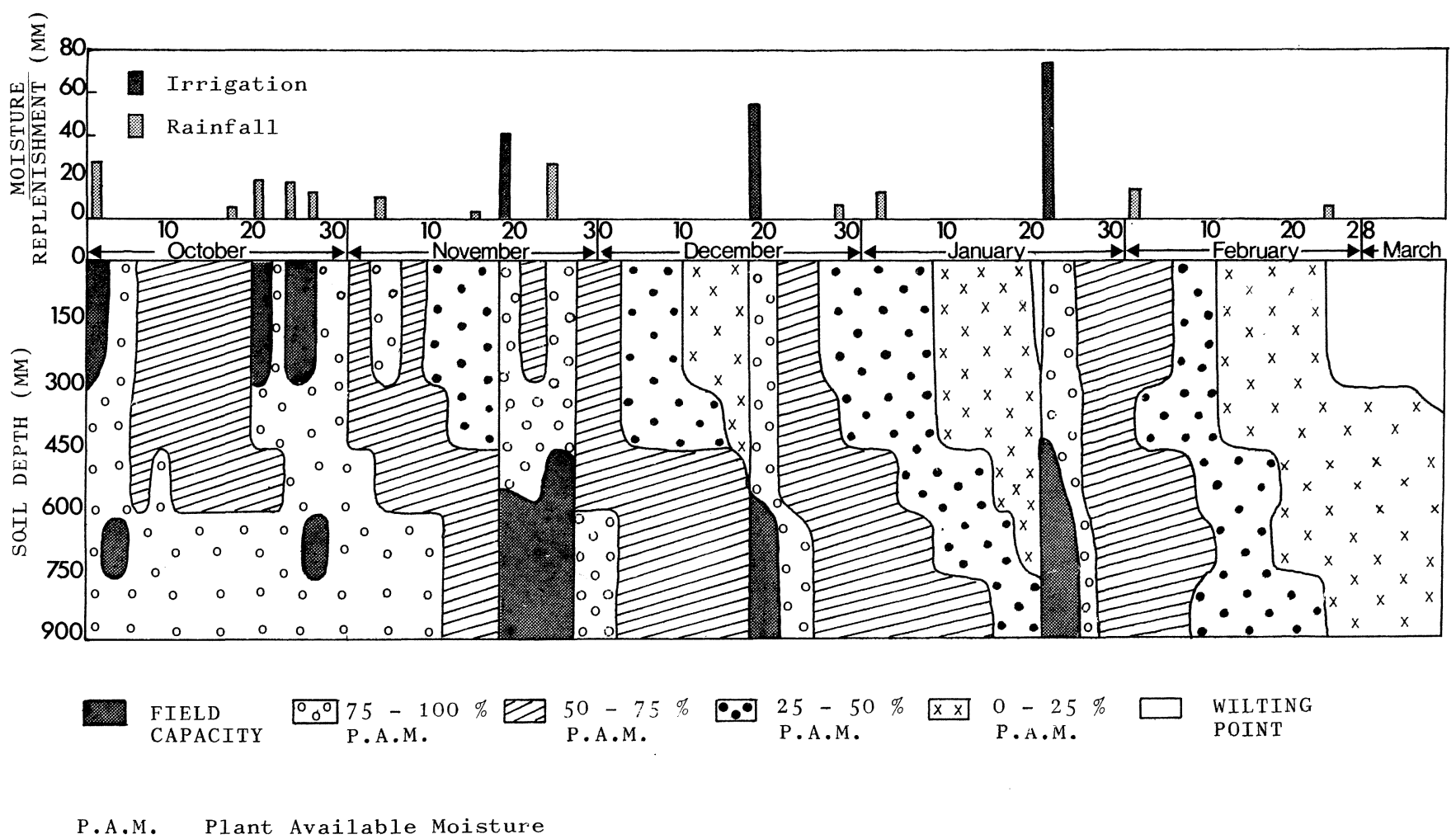

Fig. 11

Soil water content with depth in the BBB treatment during the $1974 / 75$ season.

BBB-plot even fell in a higher class for a few days (Fig. 11).

From the above it becomes clear that effective rainfall is a relative concept depending strongly amongst others on the moisture content of the soil. All rainfall is effective in its ability to diminish evapotranspiration but not always in its ability to replenish soil moisture. Furthermore, if a soil is at, or below wilting point-a not so rare occurrence in the surface layers-even $25 \mathrm{~mm}$ of rainfall will have little, if any, effect on the water supply of the vines, since the water will be absorbed in the shallowest soil layers with the fewest roots, and most of the moisture will evaporate rapidly soon afterwards.

A schematic presentation of soil water extraction patterns with depth after irrigation in three different periods of the 1973/74 season is given in Fig. 12. Examination of these diagrams reveals a shift in the pattern of water depletion.

During November the moisture extraction followed the expected pattern, viz., depletion at the highest rate near the soil surface, and decreasing with depth. This still held true in December, although the $450-600 \mathrm{~mm}$ zones, in relation to the $0-300 \mathrm{~mm}$ root zones, dried out faster than during the previous month. During January a total reversal took place. The soil moisture potentials of the $600-900 \mathrm{~mm}$ zone decreased at a faster rate than those of the shallower layers. This total change in moisture depletion pattern from November to January had been measured on all experimental plots and in both seasons (1973/74 and 1974/75). During the second season, however, a few showers replenished the moisture content of the $0-300 \mathrm{~mm}$ root zone. This could have been, to a certain extent, the cause of a slower drying of the surface soil though the change in moisture depletion pattern was still too pronounced to be attributed to this cause alone.

Soil temperature measurements (Van Huyssteen, 1977) on the same soil type and vicinity, indicate the possibility of an increased physiological activity of deep roots during January (average soil temperature of $21,2^{\circ} \mathrm{C}$ ) in comparison with November (average soil temperature of $15,9^{\circ} \mathrm{C}$ ). However, since about $90 \%$ of the total number of roots (Fig. 1) were found in the soil layers above $600 \mathrm{~mm}$ depth, this explanation seems unacceptable.

These facts lead to the conclusion that the deeper soil layers $(>600 \mathrm{~mm})$ dried at an increasingly faster rate, after irrigations, as the season progressed due to unsaturated moisture flow downwards out of the $600-900 \mathrm{~mm}$ layers under influence of a potential gradient caused by drying of deep ( $>900 \mathrm{~mm}$ ) layers beneath the rooting depth. Soil moisture measurements and moisture budgeting in this study took place to a depth of only $900 \mathrm{~mm}$, but it can now be assumed with high probability bordering on certainty that the C-horizon, which consists of deeply weathered granite with a high bulk density and low $\mathrm{pH}$, a combination of soil properties which prohibits root penetration, acts as a large reservoir for water supplied by winter rainfall. During summer this reservoir is emptied slowly by the upward movement of water into the root zone.

Keeping in mind the practical implications, both the upward and downward movement of soil water as well as the water storage capacity of the subsoil (below the root zone) should be studied in detail. Farmers commonly 


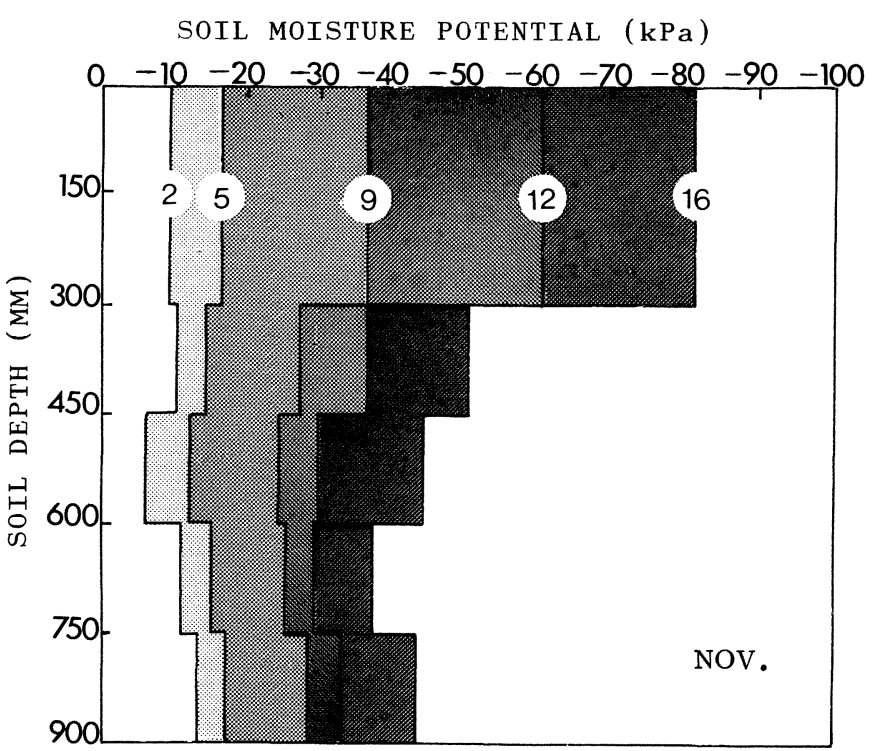

SOIL MOISTURE POTENTTAL $(\mathrm{kPa})$

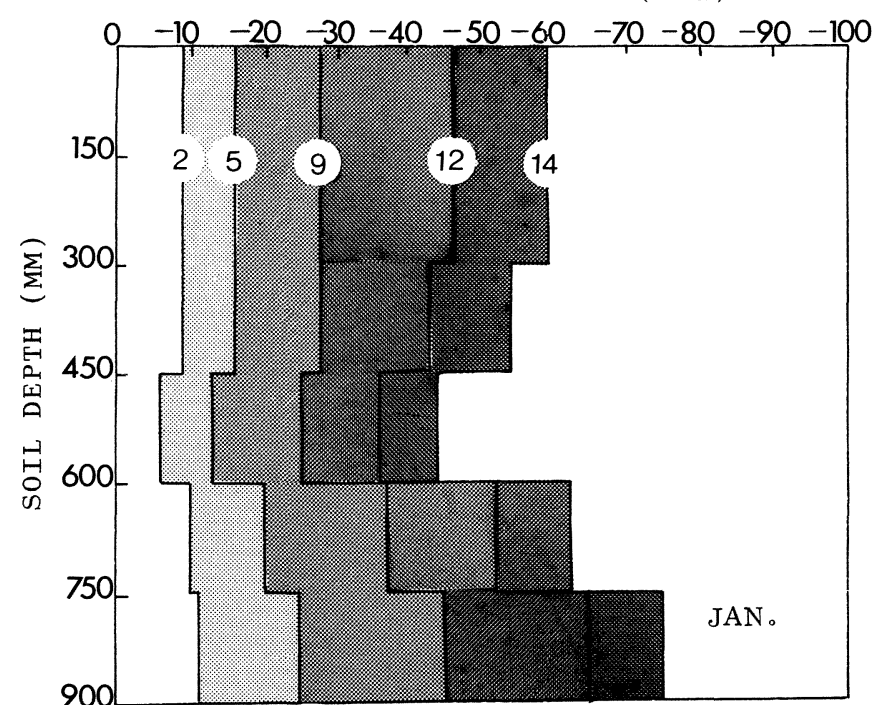

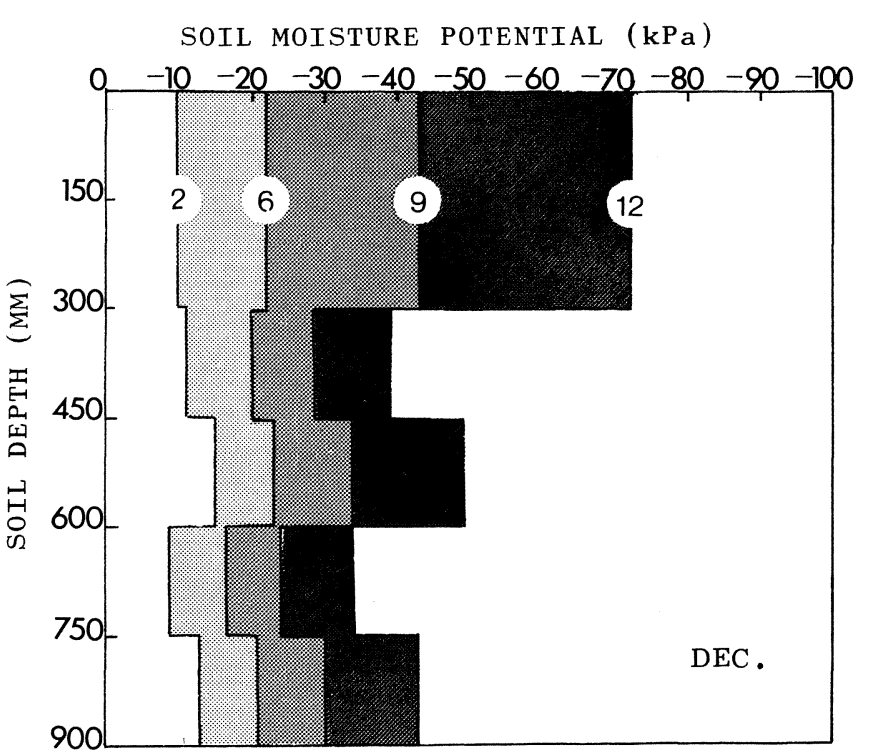

(2) $\rightarrow$ (16) Number of days after irrigations. Shaded areas represent soil moisture potential differences between days on which tensiometer readings were taken.

FIG. 12

A comparison of the soil moisture depletion patterns after irrigations on the same treatment plot during three consecutive summer months (1973/74).

believe that very wet winters usually guarantee an excellent dryland grape crop. Up to the present it was assumed, however, that only a limited part of this rainfall could be stored for summer and that the rest would drain out of reach of the roots. According to the findings of this irrigation experiment a correlation between winter rainfall and dryland vine productivity should definitely exist, since the soil moisture reservoir is apparently much larger than had been imagined. Supporting evidence comes from the work of Till (1977) who found a positive correlation between winter rainfall and dryland grape production in Australia. In the Australian experiment, however, a few roots penetrated to a depth of $6 \mathrm{~m}$.

The possible utilization of moisture stored in soil layers preventing root penetration, again focuses the interest on deep soil preparation before planting. This is common practice in the Western Cape, and one of its main aims is to enlarge the root system and thus also the soil reservoir for the storage of rainwater. However, it seems as if the beneficial effect of deep soil preparation (Claassen, Van Zyl \& Kleynhans, 1973) is not only related to the size of the soil moisture reservoir exploited by roots, but also to other factors. Furthermore, the upward movement of water into the root zone requires from researchers an extension of their investigations (especially soil moisture measurements) in the case of dryland viticulture to much greater soil depths than those indicated by the root distribution alone.

Leaf Water Potential: The plant itself provides the best indication of the water requirements of a crop, because there is a closer relationship between growth and the water status in the plant than between growth and soil moisture or atmospheric conditions (Kramer, 1962). With this in mind, the OOO and BBB treatments were compared after determination of leaf water potentials, the values of which are presented in Table 4 . Like soil water potential, leaf water potentials for both plots decreased 
TABLE 4

Leaf water potentials determined on vines of two irrigation treatments at $05 \mathrm{~h} 00$

\begin{tabular}{|c|c|c|c|c|c|c|}
\hline \multirow{2}{*}{ Date } & \multicolumn{3}{|c|}{$\begin{array}{l}\text { Leaf Water Potential } \\
\qquad(\mathrm{kPa})\end{array}$} & \multicolumn{3}{|c|}{$\begin{array}{l}\text { Total Available Moisture (TAM) } \\
\qquad(\mathrm{mm})\end{array}$} \\
\hline & $\underset{(1)}{\mathrm{OOO}}$ & $\begin{array}{c}\text { BBB } \\
(2)\end{array}$ & $\begin{array}{l}\text { Difference } \\
(1)-(2)\end{array}$ & $\underset{(3)}{\mathrm{OOO}}$ & $\begin{array}{c}\mathrm{BBB} \\
(4)\end{array}$ & $\begin{array}{l}\text { Difference } \\
(4)-(3)\end{array}$ \\
\hline $22 / 11 / 74 \ldots \ldots \ldots$ & -118 & -39 & -79 & 44,62 & 80,98 & 36,36 \\
\hline $27 / 12 / 74 \ldots \ldots \ldots$ & -141 & -83 & -58 & 0,81 & 52,01 & 51,20 \\
\hline $31 / 12 / 74 \ldots \ldots \ldots$ & -171 & -100 & -71 & $-2,21^{*}$ & 46,67 & 48,88 \\
\hline $7 / 1 / 75 \ldots \ldots \ldots$ & -215 & -100 & -115 & $-3,57^{*}$ & 40,08 & 43,65 \\
\hline $10 / 1 / 75 \ldots \ldots \ldots$ & -160 & -89 & -71 & $-4,40^{*}$ & 27,03 & 31,43 \\
\hline $14 / 1 / 75 \ldots \ldots \ldots$ & -184 & -113 & -71 & $-5,70^{*}$ & 21,48 & 27,18 \\
\hline $17 / 1 / 75 \ldots \ldots \ldots$ & -283 & -168 & -115 & $-6,34^{*}$ & 17,71 & 24,05 \\
\hline
\end{tabular}

*Moisture content below PWP

(TAM became less) from November to January. Values for the irrigated $\mathrm{BBB}$ vines were also higher than those for the dryland control vines (OOO). The differences between the two plots were, however, much smaller than would have been expected from a comparison between total available moisture contents in the soil. Furthermore, the leaf water potentials of the OOO plot were unexpectedly high (a minimum of $-283 \mathrm{kPa}$ was reached on $17 / 1 / 75$ ) in relation to the soil moisture potentials. The vines were thus able to recuperate at night from moisture stress despite the fact that the OOO plots had only 1 $\mathrm{mm}$ moisture available in the $600-900 \mathrm{~mm}$ zone (a summation of available moisture in the separate soil layers yielded a TAM $=-6,34 \mathrm{~mm}$ ).

Harvesting in that particular season took place on $6 / 3 / 75$, which meant that the OOO vines had had little or no available moisture in the root zone for more than two months (See Fig. 9). The only known source of moisture during that time was $14 \mathrm{~mm}$ of rain on the $3 \mathrm{rd}$ of February which was barely registered at $150 \mathrm{~mm}$, but did not even increase the moisture content at this depth above PWP. From February onwards the vines did show wilting symptoms, namely a yellowing and shedding of basal leaves. Despite this condition the OOO vines yielded $20 \mathrm{t} / \mathrm{ha}$ with an excellent sugar content of $22,6^{\circ} \mathrm{B}$. Similar soil moisture conditions and vine response on control plots were encountered during the previous season.

Vines from the dryland plots could probably have found moisture in one of the following ways:

(i) by extracting small amounts of moisture held at potentials lower than $-1500 \mathrm{kPa}$;

(ii) from dew condensation on the leaves, as was suggested by Van Niekerk (1968). The maximum relative humidity at night, even in January and February, was very high $(>90 \%)$ as can be seen in Fig. 13;

(iii) through utilization of moisture that moved upward from deeper soil layers into the root zone;

(iv) through condensation on roothairs and soil particles near the soil surface due to temperature and vapour pressure gradients.

According to the latter hypothesis a vapour pressure gradient exists at night between the saturated air and the dry surface soil. A temperature gradient could be expected in the same direction, especially just before dawn when the heat radiation of the soil is maximal. It would thus be possible for appreciable quantities of water vapour to diffuse into the soil and form a sub-surface dew on roothairs as well as on soil particles. The extent to which this process and other possibilities can supply water to the plant need further study.

Meteorological Irrigation Criteria: In South Africa, Class A-pan evaporation data still provide the most practical and acceptable means for the planning of irrigation schemes and, with the necessary adaptations, also for scheduling irrigations on farming level (Du Pisani, 1970a \& b). To convert Class A-pan evaporation data to evapotranspiration, a crop factor is needed for different stages of the growing season.

The variation in crop factors during the $1974 / 75$ season for two treatments is presented in Fig. $14 \& 15$. The graphs follow a characteristic pattern. Immediately after a major rainfall or an irrigation application very high crop factors were obtained. At the next set of moisture determinations (two or three days later) the crop factors were already much lower.

Several authors recognized different stages during the drying process (Hide, 1954; Vershinin et al., 1966; Hillel, 1971). Hillel (1971) recognizes two fairly distinct stages when a bare soil dries, viz.

(i) an early constant rate stage, during which the evaporation is determined by external and soil surface conditions rather than by conductive properties of the profile;

(ii) a falling rate stage, during which evaporation proceeds at a rate even lower than the evaporativity and the actual rate is dictated by the ability of the soil profile to deliver moisture to the evaporative zone.

Although crop factors are determined in the presence of both evaporation and transpiration, the initial high crop factors can be ascribed to the high surface evaporation while the soil surface is still wet. After drying of the soil surface, the consumptive water use and thus the crop factors decreased.

Crop factors determined in the experimental vineyards are presented in Table 5 .

It is noticeable that the highest crop factor $(0,36)$ was obtained during the period in which a wet soil surface and, therefore, high evaporation losses prevailed. During the $1973 / 74$ season a low factor of 0,23 was obtained for 

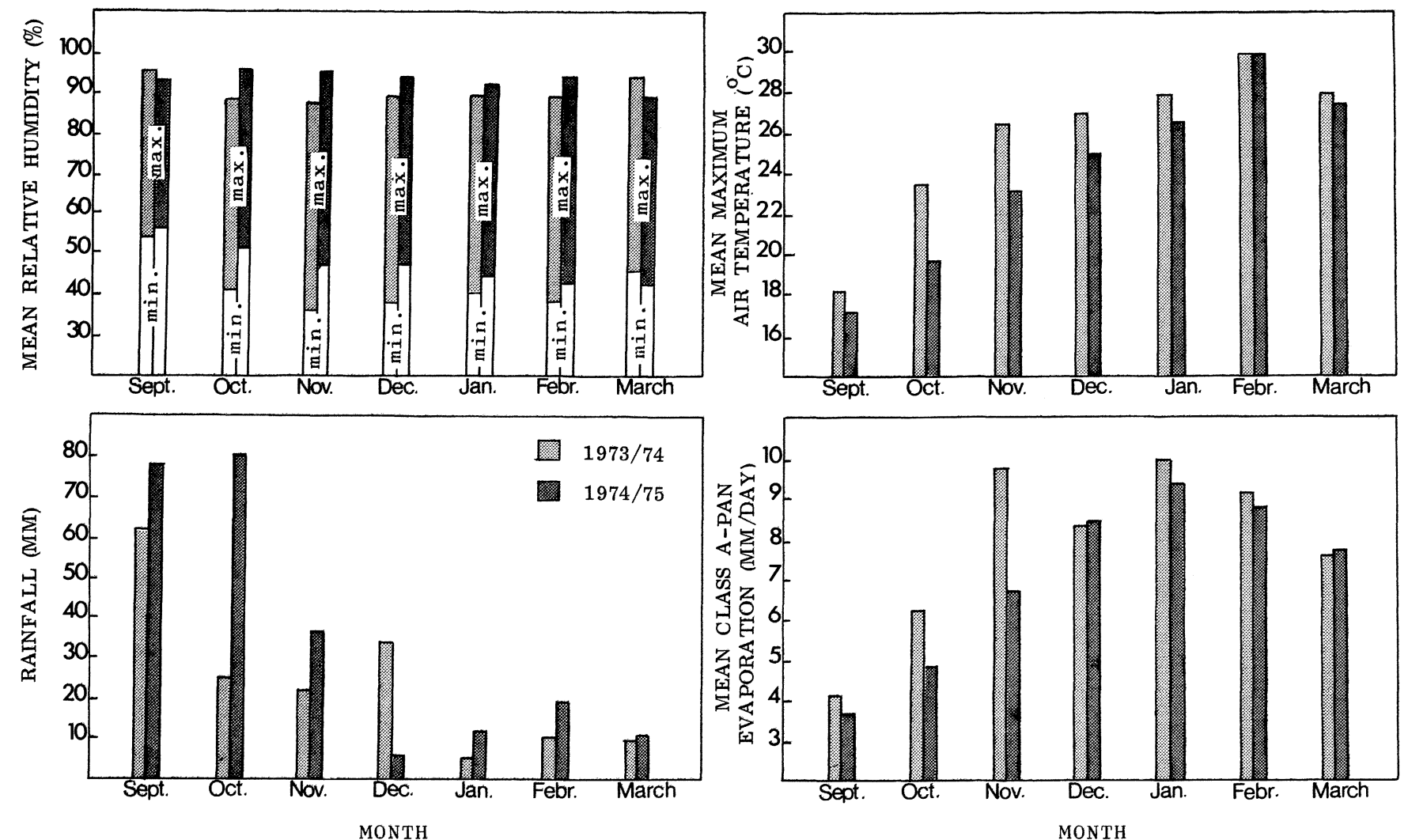

Fig. 13

Schematic illustration of several meteorological elements registered at the site of the field trial during two seasons.

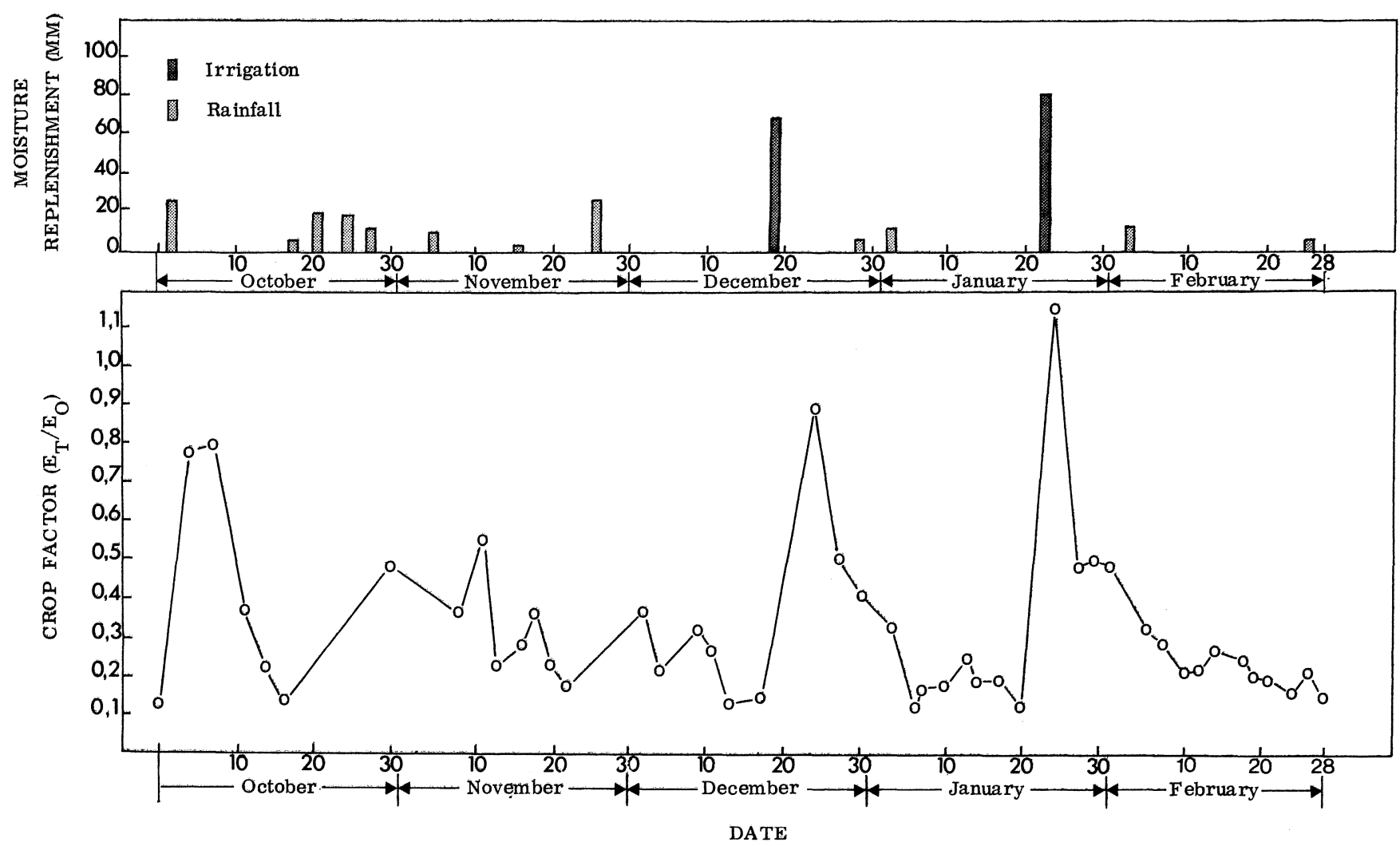

Fig. 14

Variation in crop factor values for wine grapes during the 1974/75 season (OBB treatment).

S. Afr. J. Enol. Vitic., Vol. 2. No. 2. 1981 

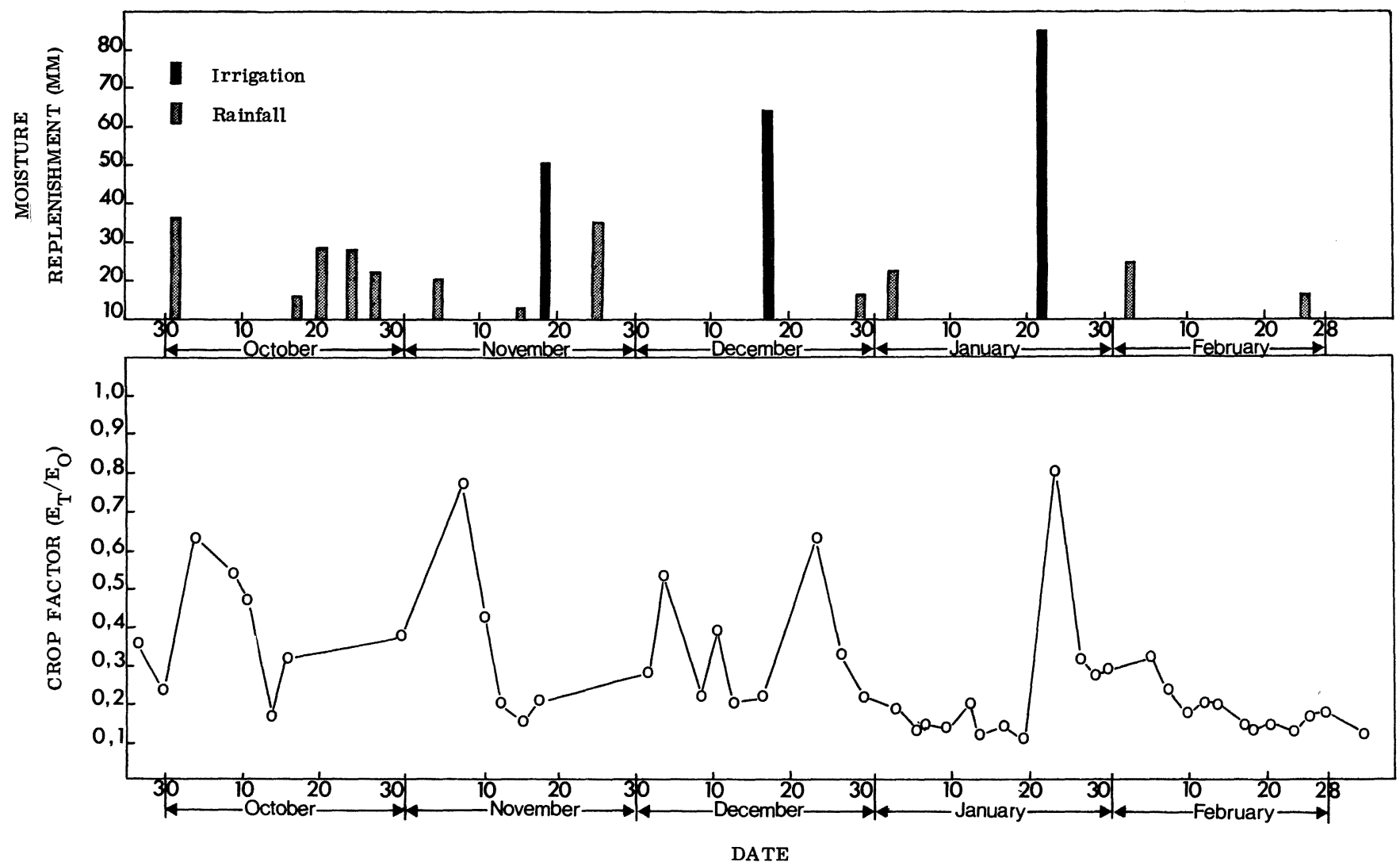

FIG. 15

Variation in crop factor values for wine grapes during the 1974/75 season (BBB treatment).

TABLE 5

Crop factors based on Class A-pan evaporation for wine grapes trellised on one wire in the Stellenbosch area

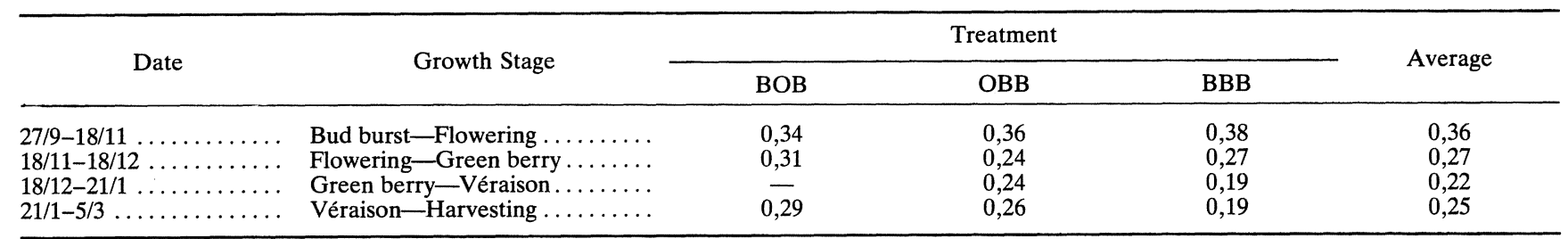

the same period, but less rain fell in the early part of the season. Crop factors for wine grapes now used by the OVRI at Stellenbosch (Saayman \& Van Zyl, 1976) are in accordance with the experimentally determined factors in Table 5. These crop factors are, however, much lower than those used earlier (Anon., 1973). Crop factors of similar low values were also used with good results in Australia (Smart, Turkington \& Evans, 1974).

The preceding discussion emphasises the fact that crop factors are not only determined by soil, climate and crop, but to a very large extent by the moisture regime maintained. The moisture regime is a function of the irrigation frequency, which can be affected by the irrigation system. It follows that a high irrigation frequency such as is usually maintained by permanent irrigation systems will lead to a higher consumptive water use than in the case of portable systems.

In Table 6 empirical coefficients for the Blaney-Criddle formula are presented. These coefficients show patterns similar to those calculated from Class A-pan evaporation.

TABLE 6

Empirical coefficients in the Blaney-Criddle formula as determined for wine grapes during different growth stages

\begin{tabular}{|c|c|c|c|c|c|}
\hline \multirow{2}{*}{ Date } & \multirow{2}{*}{ Growth Stage } & \multicolumn{3}{|c|}{ Treatment } & \multirow{2}{*}{ Average } \\
\hline & & BOB & OBB & BBB & \\
\hline 27/9-30/10 . & & - & 0,40 & 0,35 & 0,38 \\
\hline $8 / 11-18 / 11$ & Bua Burst-Flowering $\ldots \ldots \ldots$ & 0,40 & 0,39 & 0,41 & 0,40 \\
\hline $18 / 11-18 / 12$. & Flowering-Green Berry ....... & 0,41 & 0,31 & 0,35 & 0,36 \\
\hline $18 / 12-21 / 1 \ldots \ldots \ldots \ldots \ldots$ & Green Berry-Véraison ........ & - & 0,37 & 0,26 & 0,32 \\
\hline $21 / 1-5 / 3 \ldots \ldots \ldots \ldots \ldots$ & Véraison-Harvesting ......... & 0,40 & 0,40 & 0,35 & 0,38 \\
\hline
\end{tabular}


This is self-evident, since Class A-pan evaporation integrates the different meteorological elements of which temperature is an important part.

\section{CONCLUSION}

The effect of limited irrigation during certain growth stages of wine grapes was evaluated. Soil moisture measurements revealed severe moisture deficits in dryland control plots. From véraison onwards virtually no available moisture could be determined in the rooting depth of control plots. Although irrigation greatly improved the unfavourable moisture status of the soil, vine response was also affected by growth stages during which irrigation was applied. Soil moisture extraction patterns changed distinctly as the seasons progressed, and were due to movement of moisture from the wetted zone into the subsoil. Results of this study point to the importance of the contribution of the subsoil to moisture availability for the plant, and thus to the necessity of measuring soil and water properties below the root zone. Shedding more light on the apparently high drought resistance of dryland vines, leaf water potentials showed a recovery in turgidity at night of vines in soil below permanent wilting point. Crop factors were calculated from evapotranspiration and Class A-pan data. These crop factors are low, but substantiated earlier empirical estimates presently in use. The dependence of crop factors upon the soil moisture regime is stressed.

\section{LITERATURE CITED}

ALEXANDER, D. McE., 1964. The effect of high temperature regimes on short periods of water stress on development of small fruiting sultana vines. Aust. J. Agric. Res. 16, 817823.

ANON., 1973. Estimated irrigation requirements of crops in South Africa. Report printed by Dept. Agric. Tech. Serv., Pretoria. pp 157.

ASHIZAWA, M., 1964. Studies on drought damage to grape vines in the region of the the Kagawa prefecture. Mem. Fac. Agric. Kagawa 17, 69 (Abstr.: Hort. Abstr. 35, 631, 1965).

BEGG, J. E. \& TURNER, N.C., 1976. Crop water deficits, Advances in Agronomy 28, 161-217.

BLACK, J. D. F., 1976. Trickle Irrigation-A Review. Part one. Hort. Abstr. 46, 1-7.

BLANEY, H. F. \& CRIDDLE, W. D., 1950. Determining water requirements in irrigated areas from climatological and irrigation data. U.S.D.A. Soil Cons. Services. Tp.96, Washington, D.C.

BOUYOUCOS, G. J. \& MICK, A. H., 1940. An electrical resistance method for the continuous measurement of soil moisture under field conditions. Technical Bulletin 172, Michigan State College.

BRANAS, J., 1967. L'irrigation dans le Midi de la France. Progrès agric. vitic. 167, 585-597.

CLAASSEN, F. A., VAN ZYL, J. L. \& KLEYNHANS, P. H., 1973. Vordering met grondvoorbereidingsproewe op Nietvoorbij en Robertson. Die Wynboer 50, 27-30.

COLMAN, E. A., 1952. Instruction Manual: MC-300 A. Soil moisture meter and cells. Soiltest. Inc., Evanston, Ill., USA.
DU PISANI, A. L., 1970a. Calculating water consumption from weather data. Decid. Fruit Grow. 7, 163-165.

DU PISANI, A. L., 1970b. Methods for determining water requirements. Decid. Fruit Grow. 9, 245-247.

DU PISANI, A. L., 1972. 'n Statistiese vergelyking tussen gemete evapotranspirasie en weerkundige formules en elemente. Agrochemophysica 4, 63-68.

FERGUSON, W. S., 1965. Relationship between evapotranspiration by wheat and the stage of crop development. Bellani plate evaporation and soil moisture content. Can. J. Soil Sci. 45, 33-38.

GARDNER, W. R., 1968. Availability and measurement of soil water. In: Water deficits and plant growth. Vol. 1 (Ed. T. T. Kozlowski) 107-135. Academic Press, New York \& London.

GOLDBERG, D. \& SHMUELI, M., 1971. Drip irrigationmethod used under arid and desert conditions of high water and soil salinity. South African Citrus Journal 448, 9-15.

HARDIE, W. J. \& CONSIDINE, J. A., 1976. Response of grapes to water deficit stress in particular stages of development. Am. J. Enol. Vitic. 27, 55-61.

HENSLEY, M., 1970. Selected properties affecting the irrigable value of some Makatini Flat soils. M.Sc. (Agric.)-dissertation, Univ. of Natal, Pietermaritzburg.

HIDE, J. C., 1954. Observations of factors influencing the evaporation of soil moisture. Proc. Soil Sci. Soc. Am. 18, 234-239.

HILLEL, D., 1971. Soil and Water-Physical Principles and Processes p. 288 Academic Press, New York \& London.

KASIMATIS, A. N., 1967. Grapes. In: Irrigation of Agricultural Lands. (Eds. Hagan, R. M., Haise, H. R. \& Edminster, T. W.). Agron. Series 11, 719-739. Am. Soc. Agron. Madison, Wisconsin.

KRAMER, P. J., 1962. Water stress and plant growth. Agron. J. 55, 32-35.

LOMBARDO, V., 1972. Studies on the water balance in vines under semi-arid mediterranean conditions. Rivista di Viticoltura e di Enologia 25, 3-17. (Abstr.: Hort. Abstr. 42, 5702, 1972).

MACVICAR, C. N. \& SOIL SURVEY STAFF, 1977. Soil classification-a binomial system for South Africa. Dept. Agric. Tech. Serv., Pretoria.

NIEUWOUDT, A. D., 1965. Besproeiing in die Olifantsriviervallei. Tech. Bull. 47, Dept. Agric. Tech. Serv., Pretoria.

NIJAR, G. S. \& RANDHAWA, N. S., 1968. Effect of irrigation levels at different growth stages on cropping and quality of Anab-e-Shahi grapes. J. Res. Ludhiana 5, 378391. (Abstr.: Hort. Abstr. 39, 6461, 1969).

RUSSEL, R. S., 1977. Plant Root Systems: Their function and interaction with the soil p. 298 McGraw-Hill Book Company, London.

SAAYMAN, D. \& VAN ZYL, J. L., 1976. Irrigation of wine grapes in South Africa. Paper originally presented at the 14th International OIV Congress Italy 1974. Updated Oct. 1976, OVRI, Stellenbosch.

SCHEFFER, F. \& SCHACHTSCHABEL, P., 1970. Lehrbuch der Bodenkunde p. 448 Ferdinand Enke Verlag, Stuttgart.

SCHOLANDER, P. F., HAMMEL, H. T., BRADSTREET, E. D. \& HEMMINGSON, E. A., 1965. Sap pressure in vascular plants. Science 148, 339-346.

SMART, R. E., TURKINGTON, C. R. \& EVANS, J. C., 1974. Grapevine response to furrow and trickle irrigation. Am. J. Enol. Vitic. 25, 62-66.

SOIL SURVEY STAFF, 1960. Soil classification-a comprehensive system (7th Approximation). US Dept. Agric. Washington: US Govt. Printing Office.

TATARENKO, R. K., 1971. Irrigation in vineyards. Vinodelie $i$ Vinogradarstvo USSR 31, 36-37 (Abstr.: Hort. Abstr. 42, $3400,1972)$. 
TILL, M. R., 1977. The relationship between rainfall and yield of grapes in the Barossa Valley, South Australia. Soil Conservation Branch Report S8/77. South Australian Dept. of Agriculture and Fisheries.

VAN HUYSSTEEN, L., 1977. Die effektiwiteit van verskillende konvensionele en minimum grondbewerkingspraktyke in die wingerdbou. M.Sc.-thesis, Univ. Stellenbosch, Nov. 1977.

VAN NIEKERK, P. E. LE R., 1968. Soil moisture and plant water relationships with reference to the production of deciduous fruit and table grapes in the Western Province. Decid. Fruit Grow. 18, 254-259.

VAN ZYL, J. L. \& VAN HUYSSTEEN, L., 1980. Comparative studies on wine grapes on different trellising systems: 1. Consumptive water use. S. Afr. J. Enol. Vitic. 1 (1), $7-14$.
VAN ZYL, J. L. \& WEBER, H. W., 1977. Irrigation of Chenin blanc in the Stellenbosch area within the framework of the climate-soil-water-plant continuum. Proc. Int. OIV Symposium on the Quality of the Vintage. February 14-21, 1977, Cape Town, pp. 331-350.

VERSHININ, P. V., MELNIKOVA, M. K., MICHURIN B. N., MOSHKOV, B. S., POYASOV, N. A. \& CHUDNOVSKII, A. F., 1966. Fundamentals of agrophysics. (Eds. Ioffe, A. F. \& Revut, I. B.). Israel Program for Scientific Translations, Jerusalem, 1966.

VOSKANJAN, G. V., 1966. Irrigation regimes for vineyards under different hydrogeological conditions. Vinodelie Vinogradarstvo 26, 28. (Abstr.: Hort. Abstr. 37, 561, 1967).

ZINEBERG, M. S. \& BEFANI, L. I., 1962. Irrigation to provide reserve moisture. Sadovodstvo 10, 34-35. (Abstr.: Hort. Abstr. 33, 2599, 1963). 